\title{
Precolonial States and Development: Evidence from Agriculture in Africa ${ }^{1}$
}

\author{
Aditya Dasgupta ${ }^{2} \quad$ Ada Johnson-Kanu
}

Word Count:

\begin{abstract}
:
Low agricultural productivity is a major source of poverty in Africa, where much of the population works in agriculture, yet subsistence production and food insecurity are widespread. However, some pockets of agriculture in Africa are highly productive. In this paper, we assemble a geospatial dataset of all pre-colonial African states in existence between 1500 and 1850, and utilize remote-sensing data based on satellite imagery to show that areas (pixels) in proximity to the location of pre-colonial state capitals display higher levels of contemporary agricultural output. This relationship exists across and within countries, agro-ecological zones, and river basins. We rule out spurious correlation with spatial randomization tests. We argue that via pathdependence and spatial agglomeration effects, pre-colonial states transmitted the territorial reach that was critical for state-led agricultural modernization in the twentieth century. The findings support a growing literature linking contemporary economic development to state capacity transmitted from pre-colonial political institutions.
\end{abstract}

\footnotetext{
${ }^{1}$ For valuable feedback, we thank Courtenay Conrad, Elaine Denny, Andrew Shaver, Tesalia Rizzo, Jessica Trounstine and seminar participants at UC-Merced.

${ }^{2}$ Assistant Professor of Political Science, University of California, Merced: adasgupta3@ucmerced.edu.

${ }^{3} \mathrm{PhD}$ Candidate in Political Science, University of California, Merced: ajohnsonkanu@ucmerced.edu.
} 


\section{Introduction}

A major source of poverty in Africa is low levels of agricultural productivity. Over 60 percent of the African population lives in and works in rural areas. Yet subsistence production on smallholder farms and reliance on traditional technologies like shifting cultivation or low-input cultivation of unimproved crop varieties are widespread, with adverse consequences for agricultural productivity, rural incomes, and overall food security.

What explains persistently low levels of agricultural productivity in Africa? The failure of a "green revolution" - the technological revolution in agricultural productivity that took place across Asian nations between the 1960s and 1980s - to materialize in postcolonial Africa is a major puzzle in the study of comparative development. While no consensus exists, existing explanations often emphasize cultural resistance to adoption of modern agricultural practices or tropical soils unfavorable to agricultural productivity and the adoption of new technologies (see e.g. Goody 1980a; Kijima, Otsuka, and Sserunkuuma 2011).

Yet these cultural and ecological arguments are contradicted by the fact that pockets of agriculture in Africa are highly productive, when governments provide farmers with adequate access to infrastructure critical for commercial farming like irrigation, marketing and transportation infrastructure, and a functional agricultural extension bureaucracy (Juma 2015). The problem we argue, is that governments often lack the "territorial reach" to effectively provide these services to farmers in rural areas which are far from bureaucratic centers and which are disconnected from transportation and marketing networks. 
The concept of territorial reach was developed to describe differences in the capacity of bureaucracies to enforce law and order, provide critical services, and more broadly project official power across territory (see e.g. Giraudy and Luna 2017). Scholarship in the African context has documented "unevenness" or variation in the territorial reach of African states (e.g. Boone 2003; Herbst 2014; Roessler 2016). In this paper, we argue that this variation originates in pre-colonial political institutions and differences across territory in historical exposure to precolonial states. Pre-colonial states generated population centers and administrative structures which, through agglomeration effects and path dependence, colonial and post-colonial statebuilders tended to expand upon. As a result, the territorial reach of African states in the twentieth century tended to mirror the spatial extent of pre-colonial states, with important consequences for long-term agricultural development.

To test the argument, we assemble a geospatial dataset of all pre-colonial African states in existence between 1500 and 1850, and utilize remote-sensing data based on satellite imagery to show that areas (pixels) in proximity to the location of pre-colonial states display higher levels of contemporary agricultural productivity. We define proximity in terms of $25 \mathrm{~km}, 50 \mathrm{~km}, 100 \mathrm{~km}$, and $200 \mathrm{~km}$ geodesic buffer zones around the historical location of pre-colonial capital cities. We find that contemporary agricultural productivity displays large improvements with proximity to a pre-colonial capital city. This relationship exists across and within countries, agro-ecological zones, and river basins, suggesting that it is not driven by ecological factors. We rule out a potentially spurious finding of persistence due to spatial auto-correlation by conducting spatial randomization tests with randomly-generated placebo capital cities. 
Looking at mechanisms, drawing on data from Murdock's (1967) Ethnographic Atlas, we provide evidence that despite the corrosive effects of centuries of exposure to the trans-Atlantic slave trade, ethnic groups in proximity to pre-colonial state capitals were more likely to be organized politically into states at the time of their colonization by European powers at the end of the nineteenth century. Drawing on remote-sensing data on the density of roads, the spatial distribution of built-up infrastructure, on distance to markets, and on population density, we provide evidence that the reach of contemporary states tends to be concentrated around the locations of pre-colonial capital cities and to decay with distance.

The findings support a growing literature linking contemporary economic development to state capacity transmitted from pre-colonial political institutions (Herbst 2014; Boone 2003; Acemoglu and Robinson 2010; Gennaioli and Rainer 2007; Michalopoulos and Papaioannou 2013; Wilfahrt 2018; Lowes et al. 2017). We find that, despite destructive influence of centuries of the transatlantic slave trade and European imperialism, Africa's remarkably rich tradition of pre-colonial states, empires, and kingdoms exerted an important impact on long-term political and economic development. We provide evidence that the territorial reach of states and contemporary agricultural productivity mirrors the spatial extent of pre-colonial states, as a result of the transmission of administrative structures and population centers upon which colonial and post-colonial regimes built as a result of path dependence and spatial agglomeration effects. In highlighting these channels, we help to shed light on the mechanisms through which historical institutions exert long-lasting impacts on economic development (Dell, Lane, and Querubin 2018; Bockstette, Chanda, and Putterman 2002). 
The findings also contribute to the literature on the political economy of agriculture and rural development in Africa. An important literature attributes rural poverty and under-development to exploitation and excessive taxation by urban-biased elites (see e.g. Bates 2014; Kasara 2007). These arguments can be seen as theories emphasizing rent-seeking as a primary cause of rural under-development. By contrast, the findings in this paper highlight a different force: the sheer absence of meaningful state capacity in many peripheral and remote rural areas. Even rentseeking elites have an interest in improving agricultural productivity, if only to improve the taxable base of economic activity. For example, urban-biased elites successfully implemented the green revolution in much of Asia. Our findings suggest that an important constraint on agricultural development in Africa has been the limited territorial reach of states; conversely, in areas where for historical reasons the state has had the capacity to project authority into rural areas and provide farmers with critical infrastructure and connectivity to markets, highly productive agriculture is possible.

The remainder of the paper is structured as follows. First, we develop the argument about the impact that pre-colonial states exerted on contemporary agricultural development. Second, we present spatial analyses based on remote sensing data from satellite imagery. Finally, we conclude by drawing lessons about the role of pre-colonial political institutions in long-term political and economic development. 


\section{Pre-colonial States and Development in Africa}

At the time of the so-called "scramble for Africa" in the late nineteenth century, anthropologists and scholar-bureaucrats developed a narrative about African societies as politically decentralized and organized into ethnic tribes ruled by chiefs since time immemorial. A narrative that provided the basis for the arbitrary partitioning of the continent by colonial powers, and widespread indirect rule via the institutionalization of local chiefs (Mamdani 2018). In fact, recent historical, archeological, and anthropological research reveals that Africa had a rich tradition of centralized pre-colonial states, which spanned the continents many agro-ecological zones (see e.g. Vansina 1990; Monroe 2013).

Unlike Eurasian states, pre-colonial African states were organized typically not around feudal control of land, which was abundant in Africa, but around control of people and trade (Goody 1980b; Herbst 2014). However, pre-colonial states in Africa also depended upon intensive agriculture to feed large population centers. This is evident from the spatial distribution of precolonial states in Africa, which tended to form in areas suitable for agriculture like the savannah or coastal and riverine areas, and to avoid inhospitable zones like the desert or the interior of the rainforest. In this paper, we identify a list of over 80 pre-colonial states, defined as centralized polities with rulers and taxation, in existence between 1500 and 1850, based on a compilation of historical and archaeological literature (see the Appendix). In Figure 1 we depict the historical location of the capital cities of pre-colonial states on a map of African agro-ecological zones from the FAO Global Agro-ecological Zones (GAEZ) database. 


\section{FIGURE 1 ABOUT HERE}

In a context of land abundance, just like the "mandala" model of state-building found in Southeast Asia, pre-colonial states in Africa tended to project their power outward from core areas and capital cities to surrounding territories rather than defend precise territorial boundaries (Herbst 2014). Therefore, in this paper, we define exposure to pre-colonial states in terms of proximity to the coordinate of pre-colonial capitals, using geodesic buffer zones with $25 \mathrm{~km}$, $50 \mathrm{~km}, 100 \mathrm{~km}$, and $200 \mathrm{~km}$ radiuses. Based on digitization of scholarly maps representing historical estimates of the approximate territorial boundaries of pre-colonial states and kingdoms, the "core lands" of pre-colonial states rarely exceeded a 100km radius. To give an example of these patterns, in Figure 2 we depict a geo-referenced map from Vansina (1990, p. 157) of the approximate core lands and territorial boundaries of the Tio, Kongo, and Loango kingdoms in central Africa. As the figure illustrates, the $100 \mathrm{~km}$ buffer zone does a good job of approximating the "core lands" of these three kingdoms.

\section{FIGURE 2 ABOUT HERE}

Many pre-colonial states went into decline with exposure to European commercial influence, missionary activity, and the Atlantic slave trade from the sixteenth century onwards. By the time of the "scramble for Africa" over thirty of the polities in our database, like the Songhai empire, had fragmented. Others, like the Kingdom of Kongo, which survived were greatly weakened by the time of their absorption into European colonial holdings. Despite the decline of pre-colonial states, and their disappearance as autonomous political entities with European colonialism, did 
the historical residue of these pre-colonial states exert an impact on long-term state capacity and rural development? We argue that they plausibly did so. In a pattern of path-dependence commonly found in processes of state-building (see e.g. Gerring et al. 2011), colonial powers often built upon the structures - both institutions and population centers - of pre-colonial states since this was a more efficient and cost-effective way of administering a territory than building a bureaucracy from scratch. For similar reasons, post-colonial governments often built upon colonial institutions and infrastructure.

One mechanism of persistence is institutional. Considerable scholarship documents how European colonial powers tended to govern Africa "on the cheap"- failing to invest in building bureaucracy in sparsely settled rural areas because the costs of administration exceeded the potential revenues (Mamdani 2018; Kohli 2004; Herbst 2014). In this context, pre-colonial states provided the readymade local administrative architecture through which taxes could be efficiently collected and paid to colonial governments. Though these pre-colonial polities were stripped of autonomy with colonization they were often preserved and absorbed into governing institutions of indirect rule. As these areas became vital zones of tax collection, they also became relatively more attractive hubs for colonial and post-colonial regimes seeking to maximize tax revenue to target with public investments, for instance through investments in road-building and marketing networks.

A second potential mechanism of persistence is demographic. The historical literature consistently notes a relationship between pre-colonial state formation, agricultural intensification, and population density (see e.g. Vansina 1990). Pre-colonial states provided the 
centralized coordination of earth works, irrigation works, forest clearing, and other ecological "legibilization" operations required to establish intensive agriculture and food surpluses capable of supporting large population centers. Pre-colonial states also offered protection to their subjects against capture by slave traders, mitigating depopulation related to the slave trade. This plausibly resulted in a lasting legacy of more densely settled and populated zones corresponding to the territories of pre-colonial states. Greater population density plausibly made it more attractive for colonial and post-colonial regimes to invest in projecting official power and building tax collection capacity in a given territorial unit, since a greater number of people also implies a greater number of potential taxpayers. In a context of agglomeration effects, greater population density plausibly contributed to economies of scale in economic activity and the provision of public goods like irrigation, roads, and schools which require a certain level of population density to be economical. Indeed, the explicit aim of many post-colonial agricultural modernization campaigns in Africa was to forcibly move farmers from sparsely settled areas to concentrated villages where modern methods could be disseminated more efficiently (Scott 1998).

To the extent that the power of pre-colonial states radiated outward from capital cities and tended to decay with the distance, then so too plausibly did the institutional capacity and the population density that they transmitted to colonial and post-colonial regimes. The implication is that as a result of these historical influences the territorial reach of contemporary African states exhibited a pattern of decay with distance from the location of pre-colonial capitals, with important consequences for long-term agricultural development and contemporary patterns of agricultural productivity. 


\section{Spatial Analysis}

To test the argument, we link our geospatial database of pre-colonial capital cities to remotesensing measures of contemporary agricultural productivity at the pixel level based on satellite imagery. We estimate spatial regressions of the form:

$$
\begin{gathered}
\log \left(\text { Output }_{i c b z}\right)=\beta_{1} 25 \mathrm{~km}+\beta_{2} 50 \mathrm{~km}+\beta_{3} 100 \mathrm{~km}+\beta_{4} 200 \mathrm{~km}+ \\
\sum_{c} \gamma_{c} I_{i c b z}^{c}+\sum_{b} \delta_{b} I_{i c b z}^{b}+\sum_{z} \zeta_{z} I_{i c b z}^{z}+\varepsilon_{i c b z} .
\end{gathered}
$$

In this equation the outcome variable $\log \left(\mathrm{Output}_{i c b z}\right)$ represents the natural $\log$ of total agricultural output in pixel i, country c, river basin $\mathrm{b}$, and agro-ecological zone $\mathrm{z}$ on the continent of Africa. Our measure of agricultural output comes from the widely used IFPRI Spatial Allocation Model (SPAM 2010 v1.0) dataset, which uses a combination of satellite imagery and official statistics on country-level and province-level administrative data on total crop production to assign estimates of agricultural output measured in international dollars to pixels at a 5 arcminute resolution (where each pixel represents approximately $56 \mathrm{~km}^{2}$ ) for the year 2010 . A documentation can be found in (Yu et al. 2020). In brief, the SPAM database obtains satellite imagery-based estimates of land cover across pixels, exploiting the fact that different types of land cover (e.g. water bodies, forest, cropland, irrigated land, etc.) reflect solar radiation differently. It then utilizes a statistical model to assign national or provincial crop production totals across pixels. While these pixel-level estimates are characterized by measurement error, our assumption is that this error is independent of proximity to a pre-colonial capital. We take 
the natural log of the outcome variable so that the coefficients on all explanatory variables have a percentage change interpretation. Figure 3 visually depicts the distribution of log agricultural productivity in Africa.

\section{FIGURE 3 ABOUT HERE}

The explanatory variables of interest are indicator variables which take a value of one if a pixel falls within a $25 \mathrm{~km}, 50 \mathrm{~km}, 100 \mathrm{~km}$, and $200 \mathrm{~km}$ radius buffer zone, respectively, around the location of any pre-colonial city in the dataset, and a zero otherwise. These dummy variables are non-exclusive so that they must be summed to compute the marginal effect of different levels of proximity to a pre-colonial capital. For example, $\beta_{4}$ represents the impact of going from a pixel beyond $200 \mathrm{~km}$ distance from any pre-colonial capital to a pixel between $100 \mathrm{~km}$ and $200 \mathrm{~km}$ distance from a pre-colonial capital. The sum $\beta_{4}+\beta_{3}$ represents the impact of going from a pixel beyond $200 \mathrm{~km}$ distance from any pre-colonial capital to a pixel between $50-100 \mathrm{~km}$ distance from a pre-colonial capital. The sum $\beta_{4}+\beta_{3}+\beta_{2}$ represents the impact of going from a pixel beyond $200 \mathrm{~km}$ distance from any pre-colonial capital to a pixel between $25-50 \mathrm{~km}$ distance from a pre-colonial capital. The sum $\beta_{4}+\beta_{3}+\beta_{2}+\beta_{1}$ represents the impact of going from a pixel beyond $200 \mathrm{~km}$ distance from any pre-colonial capital to a pixel between $0-25 \mathrm{~km}$ distance from a pre-colonial capital.

In all specifications, we control for pixel-level variables representing average annual rainfall in millimeters, a terrain slope index (measuring hilliness), and the length in days of the annual growing season. Each of these variables comes from raster files in the FAO GAEZ (v 3.0) 
database. Depending on the specification, we also control for country fixed effects, $\sum_{c} \gamma_{c} I_{i c b z}^{c}$, river basin fixed effects, $\sum_{b} \delta_{b} I_{i c b z}^{b}$, agro-ecological zone fixed effects, $\sum_{z} \zeta_{z} I_{i c b z}^{Z}$, or all three fixed effects simultaneously. There are fifty major countries in the dataset, as well as 25 major river basins and 16 agro-ecological zones. Controlling for river basin (or country or agroecological zone) fixed effects ensures that only comparisons between pixels with more, or less proximity to a pre-colonial capital within the same river basin (or country or agroecological zone) drive the estimates. Controlling for these variables helps to ensure that potential confounding variables related to ecology do not drive estimates. We also estimate standard errors adjusted for three-way clustering within countries, river basins, and agro-ecological zones in all specifications to address potential spatial auto-correlation.

\section{TABLE 1 ABOUT HERE}

Table 1 reports the main results. Panel A examines the impact on pixel-level measures of contemporary agricultural productivity for all crops. The positive coefficients in the baseline specification without any fixed effects suggests that contemporary agricultural productivity improves with proximity to a pre-colonial capital city. While the coefficients from all of the specifications tell a similar story, we focus on our preferred specification in column (5) which includes all three of the agro-ecological zone, river basin, and country fixed effects. These help to ensure that unobserved ecological differences, for instance, between the desert and the savannah, or between the Congo river basin and the Nile river basin, or between Kenya and Nigeria, do not confound the estimates. 
The coefficients in column (5) imply that going from pixels more than 200km away from any pre-colonial capital to pixels located within a 100-200km buffer zone around a pre-colonial capital is associated with a 180 percent improvement in the value of total agricultural output in a pixel. Going from pixels more than $200 \mathrm{~km}$ away from any pre-colonial capital to pixels located within a $50-100 \mathrm{~km}$ buffer zone is associated with a 247 percent improvement in total agricultural output. Going from pixels more than $200 \mathrm{~km}$ away from any pre-colonial capital to pixels located within a $25-50 \mathrm{~km}$ buffer zone is associated with a 287 percent improvement in agricultural output. Going from pixels more than $200 \mathrm{~km}$ away from any pre-colonial capital to pixels located within a $0-25 \mathrm{~km}$ buffer zone is associated with an over 300 percent improvement in agricultural output. Panel B focuses on estimated measures of output for food crops alone while panel C focuses on measures of output for non-food crops. We depict the marginal effect of different levels of proximity to a pre-colonial capital city on total agricultural output as well as for food and non-food crops in Figure 4.

\section{FIGURE 4 ABOUT HERE}

By controlling for a range of confounding variables related to ecological suitability for agriculture, we have helped to rule out the concern that ecological differences drive the result. But could the finding of persistent effects of proximity to a pre-colonial kingdom on contemporary agricultural output also be a spurious correlation arising from regressing two spatially correlated variables against one another? This is an important concern in historical research. In our context, both the spatial distribution of pre-colonial states as well as agricultural productivity display spatial auto-correlation, which we have sought to address statistically with 
standard errors clustered at the level of countries, river basins, and agro-ecological zones. However, these parametric approaches can fail for a number of reasons, including clustering standard errors at the incorrect level of aggregation (Barrios et al. 2012).

To address this, we conduct non-parametric tests of statistical significance using spatial randomization tests. To perform these tests, we generate samples of placebo capital cities by randomly generating coordinates (equal in number to the number of true pre-colonial capitals) and re-estimate our regression models with these placebo datasets many times to generate a distribution of placebo estimates against which estimates based on the location of true precolonial capitals can be compared. We can compute p-values from these distributions by computing the share of placebo estimates larger than the estimates based on the location of true pre-colonial capitals.

\section{FIGURE 5 ABOUT HERE}

In one version of the procedure, we randomly generate capitals from across the African continent. In another version of this analysis, designed to mimic the spatial distribution of true pre-colonial capitals, we conduct a stratified random selection of placebo coordinates within river basins, so that the distribution of placebo capitals across river basins is the same as that of the true pre-colonial capitals. Figure 5 displays a map of river basins along with the location of true capital cities in panel A and an example of randomly generated placebo capitals in panel B. The results of the analysis are reported in Table 2. Using both all-Africa and river basin-stratified random generation of placebo capitals, we find that it is extremely unlikely that we arrive at our 
estimates by chance due to the spatial structure of the data, with non-parametric p-values that tend to be smaller than those obtained parametrically.

\section{TABLE 2 ABOUT HERE}

How does contemporary agricultural productivity display large improvements with proximity to a pre-colonial capital city? There are two mechanisms. Proximity could improve agricultural output on the extensive margin by leading to improvements in the share of land within a pixel allocated to cropland. Proximity could also improve agricultural output on the intensive margin by improving the productivity of land with improved usage of inputs and modern techniques and technologies, such as irrigation and multiple-cropping. In Table 3 we examine these different possibilities. Panel A reveals that pixels in greater proximity to pre-colonial capitals are characterized by large improvements in the share of allocated cropland (based on remote-sensing data). In Panels B and C, we explore whether this is driven by an expansion of rainfed or irrigated cropland; there is evidence for both, with no aggregate change in the share of cropland that is irrigated.

\section{TABLE 3 ABOUT HERE}

Together the results indicate that proximity to a pre-colonial capital primarily improves agricultural output on the extensive margin, improving the share of land that is dedicated to agriculture and only modestly improving the technologies that are applied to the land. This is

reflected in the estimates in Panel D, where we compute a measure of per hectare productivity, 
which can be thought of as a measure of how intensively a fixed plot of land is cultivated. These estimates are positive but small in magnitude and not statistically significant. In Figure 6, we depict the marginal effect of proximity to a pre-colonial capital on the intensive and extensive margins of agricultural output. These results indicating that proximity is associated with improvements in agricultural output on the extensive margin are potentially consistent with improved state territorial reach in areas in proximity to a pre-colonial state, since enforcement of property rights, investment in roads, storage and transportation infrastructure, and access to markets are all factors which contribute to the expansion of cropland beyond smallholder subsistence plots.

\section{FIGURE 6 ABOUT HERE}

How did pre-colonial states transmit territorial reach to colonial and post-colonial regimes? Evidence of institutional persistence must be provided to understand this. As a first step, we provide evidence that ethnic groups in proximity to any pre-colonial state in existence between 1500 and 1850 were still more likely to be organized politically into states at the time of their colonization by European power at the end of the nineteenth century. To measure political organization at the time of colonization we rely on the Ethnographic Atlas published by Murdock (1967), which divides the African continent into spatially contiguous "ethnic homelands" and classifies each ethnic group's form of political organization at the time of colonization as a "large state", "small state", "large chiefdom", "petty chiefdom" or "acephalous society" (for an analysis of this data see e.g. Michalopoulos and Papaioannou 2013). 


\section{TABLE 4 ABOUT HERE}

In Table 4 we examine the impact of proximity to a pre-colonial capital on the form of political organization at the time of colonization, where we assign to each pixel the form of political organization of the ethnic group whose boundaries within the pixel falls. To address the multiplication of multiple pixels which take the same value within ethnic homelands, we additionally adjust standard errors for clustering within ethnic homelands in this analysis. Panel A looks at the impact on state-based political organization. Our preferred specification in column

(5) suggests that going from pixels more than $200 \mathrm{~km}$ away from any pre-colonial capital to pixels located within a $100-200 \mathrm{~km}$ buffer zone is associated with a 12.7 percentage point improvement in the probability of state-based political organization at the time of colonization. Going from pixels more than $200 \mathrm{~km}$ away from any pre-colonial capital to pixels located within a $50-100 \mathrm{~km}$ buffer zone is associated with a 24.5 percentage point improvement in the probability of state-based political organization at the time of colonization. Going from pixels more than $200 \mathrm{~km}$ away from any pre-colonial capital to pixels located within a $25-50 \mathrm{~km}$ buffer zone is associated with a 30-percentage point improvement in the probability of state-based political organization at the time of colonization. Going from pixels more than $200 \mathrm{~km}$ away from any pre-colonial capital to pixels located within a $25-50 \mathrm{~km}$ buffer zone is associated with a 33.5 percentage point improvement in the probability of state-based political organization at the time of colonization.

FIGURE 7 ABOUT HERE 
By contrast, we find no evidence that proximity to any pre-colonial state increased the probability of chiefdom-based political organization at the time of colonization, challenging the idea that chiefdoms can be thought of as an intermediate form of political centralization on the path to state-based organization. There appears to be a modest, positive association between proximity to any pre-colonial state and acephalous societies at the time of colonization, likely in some areas where pre-colonial states experienced severe fragmentation and decline. We display marginal effects in Figure 7. Together, these findings suggest that the institutional and administrative structures generated by pre-colonial states in our database persisted at least through the time of colonization by European powers, plausibly transmitting administrative and taxation structure upon which colonial regimes built, and shaping the territorial reach of colonial regimes.

Did these patterns of state territorial reach that improved with proximity to pre-colonial capitals and decayed with distance persist to the twentieth century? To empirically measure the territorial reach of contemporary African states, we rely on remote-sensing measures of physical infrastructure, including pixel-level estimates of the density of roads (length of road in kilometers/square kilometer of land), which comes from the GRIP global roads database (Meijer et al. 2018), as well as pixel level estimates of the percentage of built-up land (buildings, paved roads, and other cement structures), which comes from the FAO GAEZ database for the year 2000. To study connectivity to marketing networks, we also look at a pixel-level estimate of the approximate travel time in hours to the nearest market, which also comes from the FAO GAEZ database. To study the persistence of pre-colonial population centers through spatial agglomeration effects, we utilize the Gridded Population of the World (GPW) dataset, which 
provides estimates of people per square kilometer for the year 2010. We regress each of these variables on the indicator of proximity to any pre-colonial state capital in existence between 1500 and 1850 in Table 5.

\section{TABLE 5 ABOUT HERE}

Across outcome variables, we find evidence that the reach of the state plausibly improves with proximity to a pre-colonial capital. Panel A examines the impact of proximity to a pre-colonial state capital on road density. The estimates in the preferred specification in column (5) reveal a pattern of modest improvements in road density up to a buffer zone of 50 kilometers, followed by a massive increase within a 25 kilometer buffer zone, plausibly corresponding the presence of contemporary states which formed in the vicinity of pre-colonial states due to agglomeration effects. Panel B examines the impact on built-up area, which also displays a pattern of improved infrastructure coverage with proximity to a pre-colonial capital, and which shows a particularly large increase within a buffer zone of 25 kilometers. Panel C explores the impact on connectivity to marketing networks as measured by an estimate of travel time to the nearest market in hours. Here too, farmers benefit from improving connectivity (travel time to market falls) the closer they are in proximity to a pre-colonial capital. Panel D explores the impact on population density. The results suggest that, plausibly as a result of agglomeration effects that concentrated public investment and population growth around population centers established by pre-colonial states, pixels in proximity to pre-colonial capitals display higher levels of population density, with a particularly large increase reflecting urban zones within a $25 \mathrm{~km}$ buffer zone. Figure 8 displays computes marginal effects. 


\section{FIGURE 8 ABOUT HERE}

\section{Conclusion}

In this paper, we sought to understand the problem of low levels of agricultural productivity - a major source of poverty and food insecurity. We assembled a geospatial dataset of all precolonial African states in existence between 1500 and 1850, and utilized remote-sensing data based on satellite imagery to show that areas (pixels) in proximity to the location of pre-colonial capitals display higher levels of contemporary agricultural output. We argued that pre-colonial states transmitted administrative structures and population centers upon which colonial and postcolonial regimes built, as reflected in the concentration of contemporary territorial reach and agricultural productivity around pre-colonial capitals.

The findings highlight how pre-colonial political institutions, by shaping the colonial and postcolonial projects of state-building, shape long-term political and economic development. In this paper, we have highlighted as particularly important how the territorial reach of contemporary states or their ability to enforce law and order, provide critical services, and project official authority across territory tends to mirror the spatial extent of pre-colonial states. Pre-colonial institutions and historical states could also plausibly shape other aspects of contemporary states and societies and further empirical work on different potential channels would be a valuable avenue for further inquiry. 
The findings also speak to a puzzle in the study of comparative development: the failure of a "green revolution" to materialize in postcolonial Africa. In Asia, colonial power preserved and built upon the administrative structure of highly centralized "hydraulic empires", a source of institutional continuity which provided the administrative infrastructure and territorial reach that colonial and post-colonial regimes needed to successfully broadcast power throughout the countryside and modernize agriculture. In contrast, centuries of the transatlantic slave trade and European commercial imperialism destroyed Africa's rich tradition of pre-colonial states and the degree of institutional continuity between pre-colonial political traditions, and colonial and postcolonial states was far weaker (Engelbart 2002), leaving contemporary states in a far weaker position in terms of their ability to penetrate the countryside and successfully conduct agricultural modernization.

Even in this institutionally destructive context, the administrative structures and population centers that pre-colonial states in Africa left behind continue to exert a positive influence on contemporary state capacity and agricultural development. This is evidence in contemporary patterns of agricultural output. An interesting avenue for future research would be to explore whether other indicators of rural development, perhaps measured through satellite imagery, display a similar pattern. 


\section{Bibliography}

Acemoglu, Daron, and James A. Robinson. 2010. “Why Is Africa Poor?” Economic History of Developing Regions 25 (1): 21-50.

Barrios, Thomas, Rebecca Diamond, Guido W. Imbens, and Michal Kolesár. 2012. "Clustering, Spatial Correlations, and Randomization Inference." Journal of the American Statistical Association 107 (498): 578-91.

Bates, Robert H. 2014. Markets and States in Tropical Africa: The Political Basis of Agricultural Policies. University of California Press.

Bockstette, Valerie, Areendam Chanda, and Louis Putterman. 2002. "States and Markets: The Advantage of an Early Start." Journal of Economic Growth 7 (4): 347-69.

Boone, Catherine. 2003. Political Topographies of the African State: Territorial Authority and Institutional Choice. Cambridge University Press.

Dell, Melissa, Nathan Lane, and Pablo Querubin. 2018. "The Historical State, Local Collective Action, and Economic Development in Vietnam." Econometrica 86 (6): 2083-2121.

Englebert, Pierre. 2002. State Legitimacy and Development in Africa. Lynne Rienner Publishers.

Gennaioli, Nicola, and Ilia Rainer. 2007. "The Modern Impact of Precolonial Centralization in Africa." Journal of Economic Growth 12 (3): 185-234.

Gerring, John, Daniel Ziblatt, Johan Van Gorp, and Julian Arevalo. 2011. “An Institutional Theory of Direct and Indirect Rule." World Politics, 377-433.

Giraudy, Agustina, and Juan Pablo Luna. 2017. "Unpacking the State's Uneven Territorial Reach: Evidence from Latin America." States in the Developing World, 93-120.

Goody, Jack. 1980a. "Rice-burning and the Green Revolution in Northern Ghana." The Journal of Development Studies 16 (2): 136-55.

. 1980b. Technology, Tradition and the State in Africa. CUP Archive.

Herbst, Jeffrey. 2014. States and Power in Africa: Comparative Lessons in Authority and Control. Vol. 149. Princeton University Press.

Juma, Calestous. 2015. The New Harvest: Agricultural Innovation in Africa. Oxford University Press.

Kasara, Kimuli. 2007. "Tax Me If You Can: Ethnic Geography, Democracy, and the Taxation of Agriculture in Africa." American Political Science Review, 159-72.

Kijima, Yoko, Keijiro Otsuka, and Dick Sserunkuuma. 2011. "An Inquiry into Constraints on a Green Revolution in Sub-Saharan Africa: The Case of NERICA Rice in Uganda." World Development 39 (1): 77-86.

Kohli, Atul. 2004. State-Directed Development: Political Power and Industrialization in the Global Periphery. Cambridge university press.

Lowes, Sara, Nathan Nunn, James A. Robinson, and Jonathan L. Weigel. 2017. "The Evolution of Culture and Institutions: Evidence from the Kuba Kingdom." Econometrica 85 (4): 1065-91.

Mamdani, Mahmood. 2018. Citizen and Subject: Contemporary Africa and the Legacy of Late Colonialism. Princeton University Press.

Meijer, Johan R., Mark AJ Huijbregts, Kees CGJ Schotten, and Aafke M. Schipper. 2018. "Global Patterns of Current and Future Road Infrastructure." Environmental Research Letters 13 (6): 064006.

Michalopoulos, Stelios, and Elias Papaioannou. 2013. "Pre-colonial Ethnic Institutions and Contemporary African Development." Econometrica 81 (1): 113-52. 
Monroe, J. Cameron. 2013. "Power and Agency in Precolonial African States." Annual Review of Anthropology 42.

Murdock, George Peter. 1967. "Ethnographic Atlas: A Summary.” Ethnology 6 (2): 109-236.

Roessler, Philip. 2016. Ethnic Politics and State Power in Africa: The Logic of the Coup-Civil War Trap. Cambridge University Press.

Scott, James C. 1998. Seeing like a State: How Certain Schemes to Improve the Human Condition Have Failed. Yale University Press.

Vansina, Jan M. 1990. Paths in the Rainforests: Toward a History of Political Tradition in Equatorial Africa. University of Wisconsin Pres.

Wilfahrt, Martha. 2018. "Precolonial Legacies and Institutional Congruence in Public Goods Delivery: Evidence from Decentralized West Africa.” World Politics 70 (2): 239-74.

Yu, Qiangyi, Liangzhi You, Ulrike Wood-Sichra, Yating Ru, Alison KB Joglekar, Steffen Fritz, Wei Xiong, Miao Lu, Wenbin Wu, and Peng Yang. 2020. "A Cultivated Planet in 2010: 2. the Global Gridded Agricultural Production Maps.” Earth System Science Data. 


\section{Tables and Figures}

Figure 1: Geodesic Buffer Zones Around Pre-colonial Capital Cities

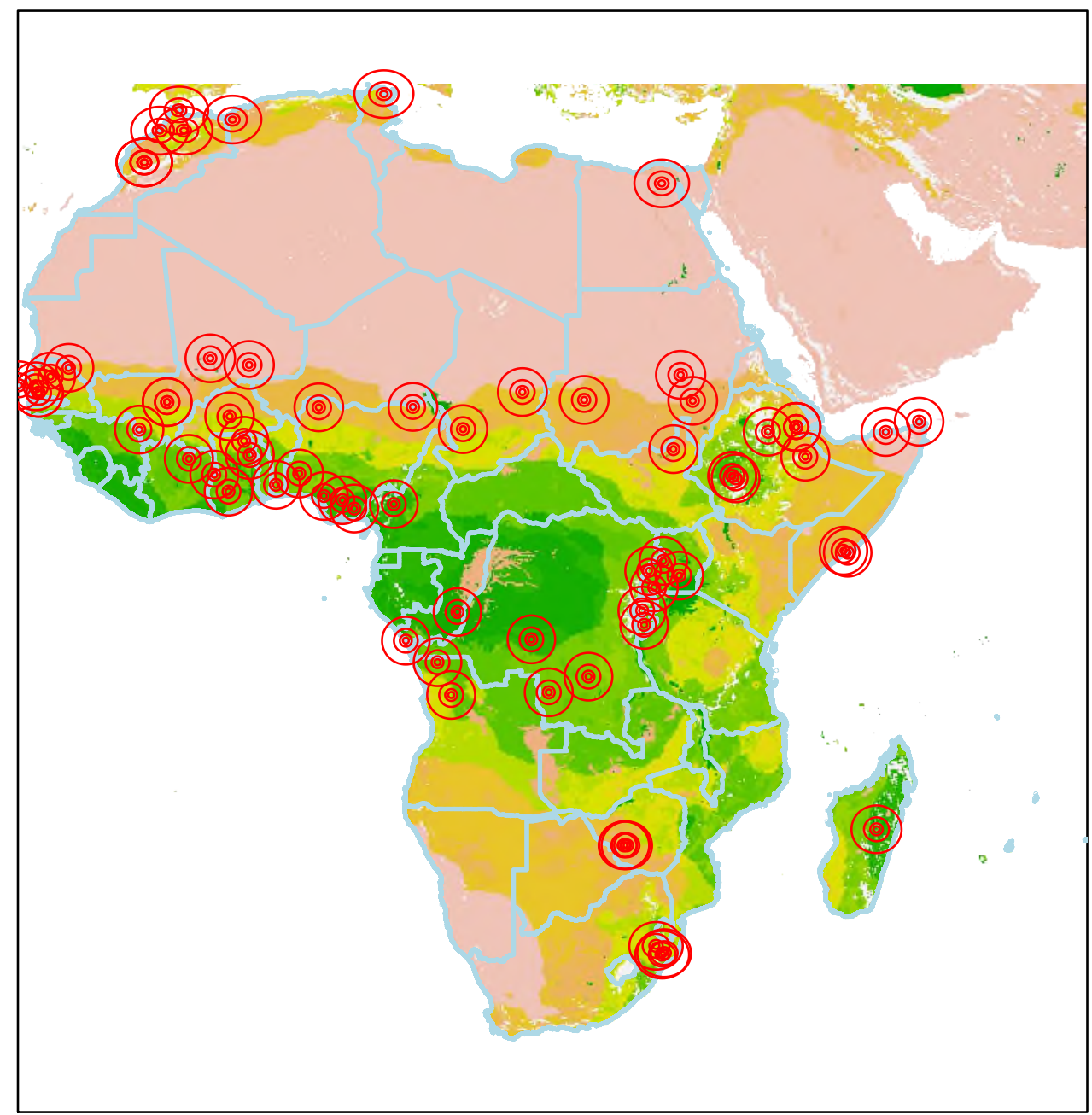

Notes: Plot depicts agro-ecological zones in Africa with $25 \mathrm{~km}, 50 \mathrm{~km}, 100 \mathrm{~km}$, and $200 \mathrm{~km}$ radius geodesic buffer zones around the locations of the capital cities of pre-colonial states. Boundaries of contemporary African states are in light blue. 
Figure 2: Comparison of Buffer Zones to Estimated Historical Boundaries

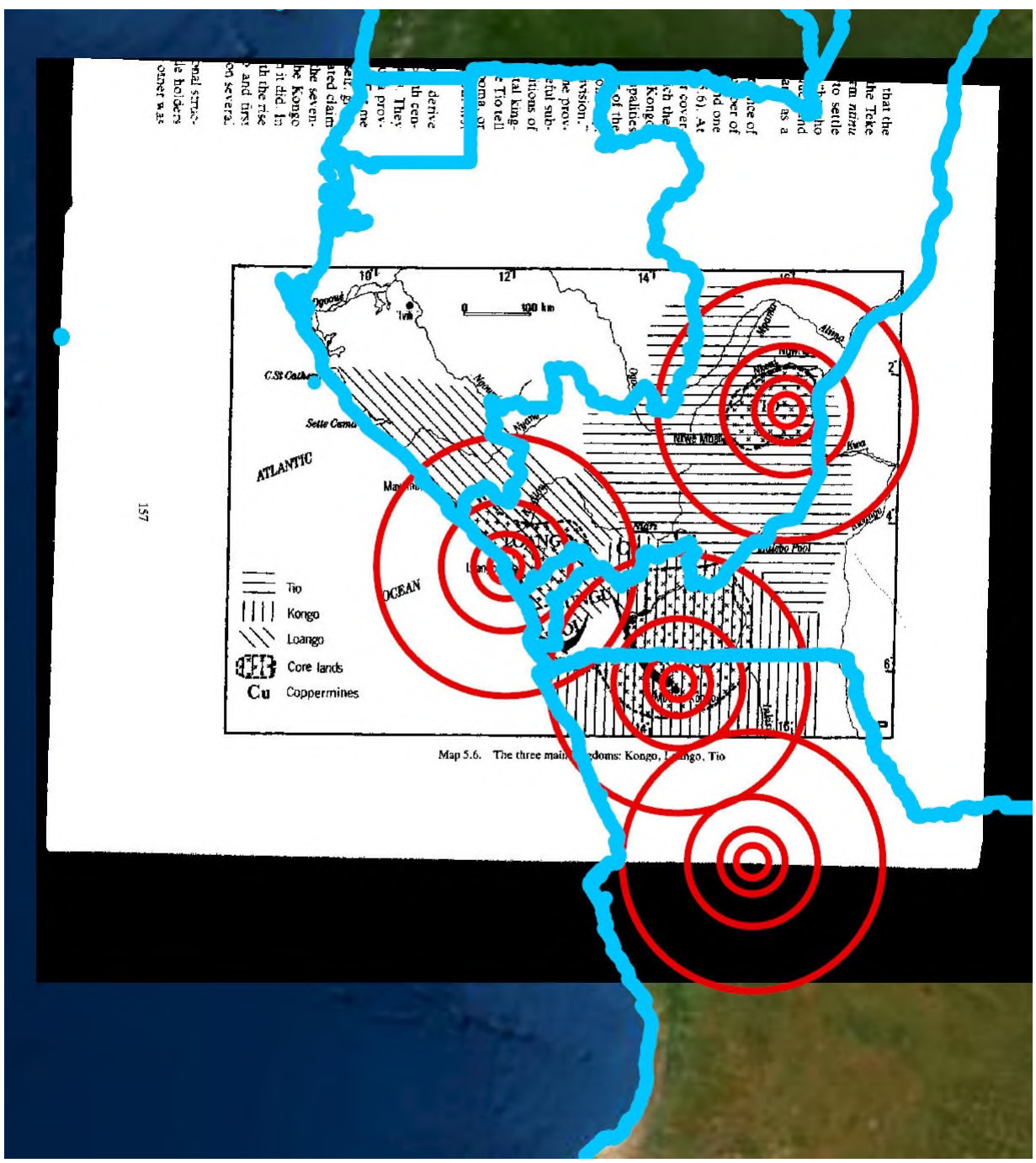

Notes: Plot depicts geo-referenced map of estimated historical boundaries of the Kongo, Tio, and Loango kingdoms from Vansina ("Paths in the Rainforest" 1990, p. 157) compared against 25km, 50km, 100km, and 200km radius geodesic buffer zones around the locations of the capital cities of these pre-colonial states. Boundaries of contemporary African states are in light blue. The authors are in the process of collected geo-referenced historical maps for each of pre-colonial states in the dataset, which will be converted into shapefiles for additional analyses. 
Figure 3: Pixel-level Estimates of Agricultural Output

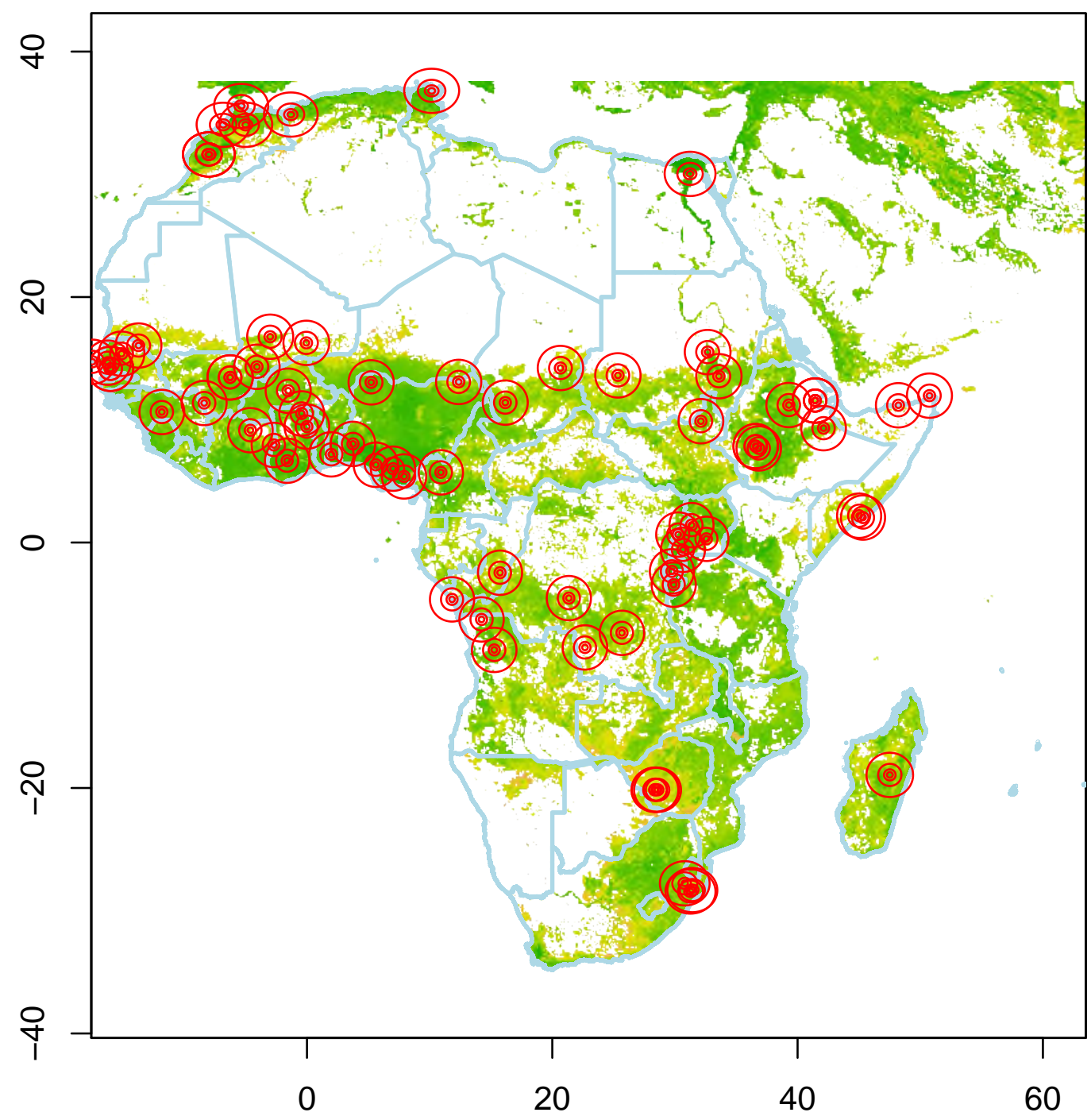

Notes: Plot depicts a raster file of pixel level estimates of the log of the value of total agricultural output in international dollars (plus 1 to account for pixels with no agricultural output). Plot also depicts $25 \mathrm{~km}, 50 \mathrm{~km}$, $100 \mathrm{~km}$, and $200 \mathrm{~km}$ radius geodesic buffer zones around the locations of the capital cities of pre-colonial states 


\section{Table 1: Proximity to Pre-colonial Capital and Agricultural Productivity}

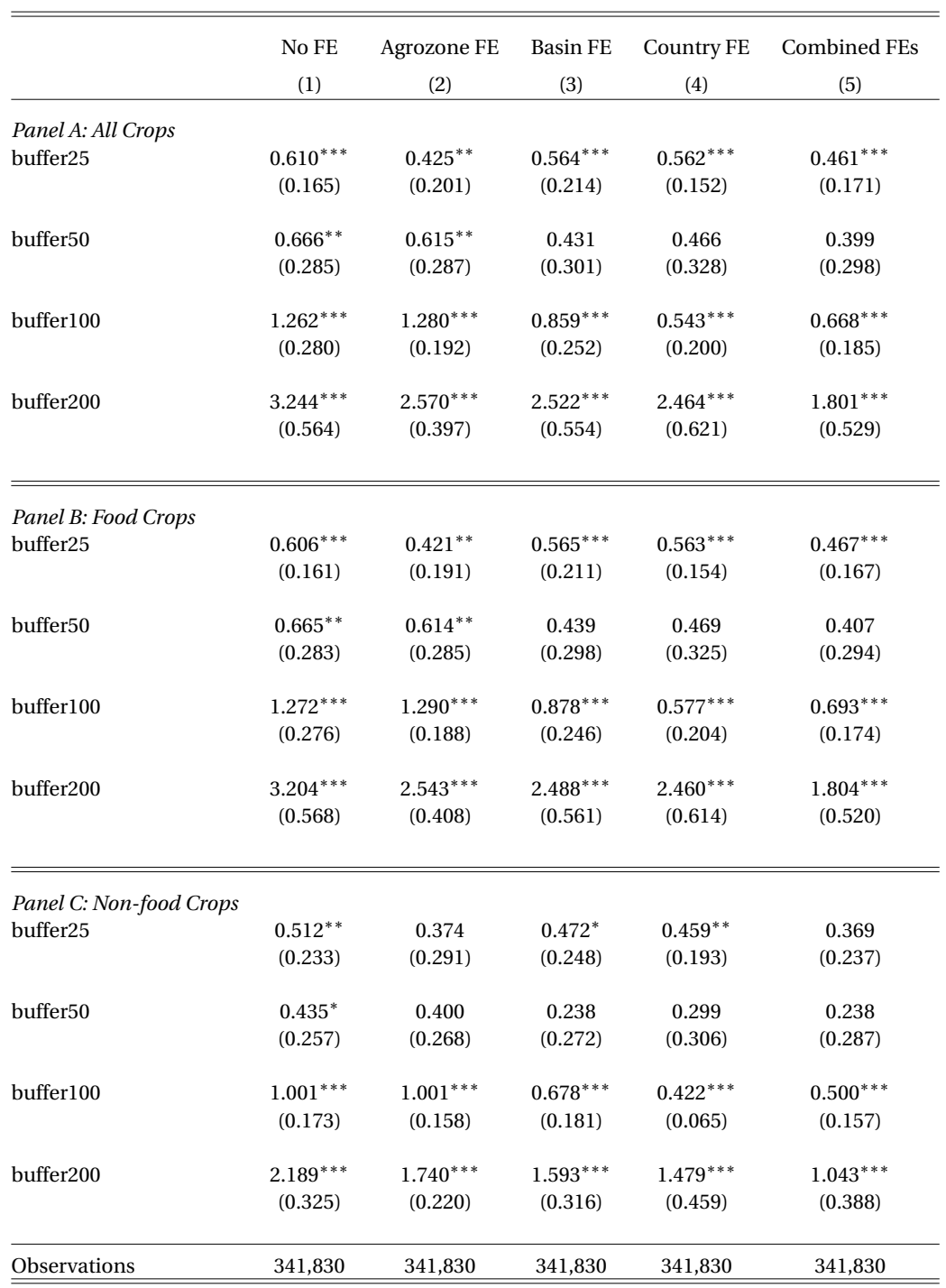

Notes: Unit of analysis is pixels $\left(5 \times 5\right.$ arc-minute resolution or approximately $\left.56 \mathrm{~km}^{2}\right)$ on African continent, masking inland water bodies. Outcome is the natural log of total agricultural output (for all crops, food crops, and non-food crops, respectively) within each pixel based on estimates from remote-sensing data. Explanatory variables are dummy variables for whether a pixel is located within a $25 \mathrm{~km}, 50 \mathrm{~km}, 100 \mathrm{~km}$ or $200 \mathrm{~km}$ ) radius around the location of any pre-colonial capital city in the database. The dummy variables are non-exclusive so that dummy variables must be added to compute marginal impacts (for example the marginal impact of falling within a $25 \mathrm{~km}$ radius around a pre-colonial capital city is computed by taking the sum of the coefficients on the within- $25 \mathrm{~km}, 50 \mathrm{~km}, 100 \mathrm{~km}$, and $200 \mathrm{~km}$ radius dummies). Specifications include, respectively, either no fixed effects, agro-ecological zone fixed effects, river basin fixed effects, country fixed effects, or all three. All specifications control for a terrain slope index, average annual precipitation, and the length of the annual growing period. Standard errors adjusted for three-way clustering within agro-ecological zones, river basins, and countries. ${ }^{*} \mathrm{p}<0.1 ;{ }^{* *} \mathrm{p}<0.05 ;{ }^{* * *} \mathrm{p}<0.01$ 
Figure 4: Marginal Effect of Proximity to Precolonial Capital
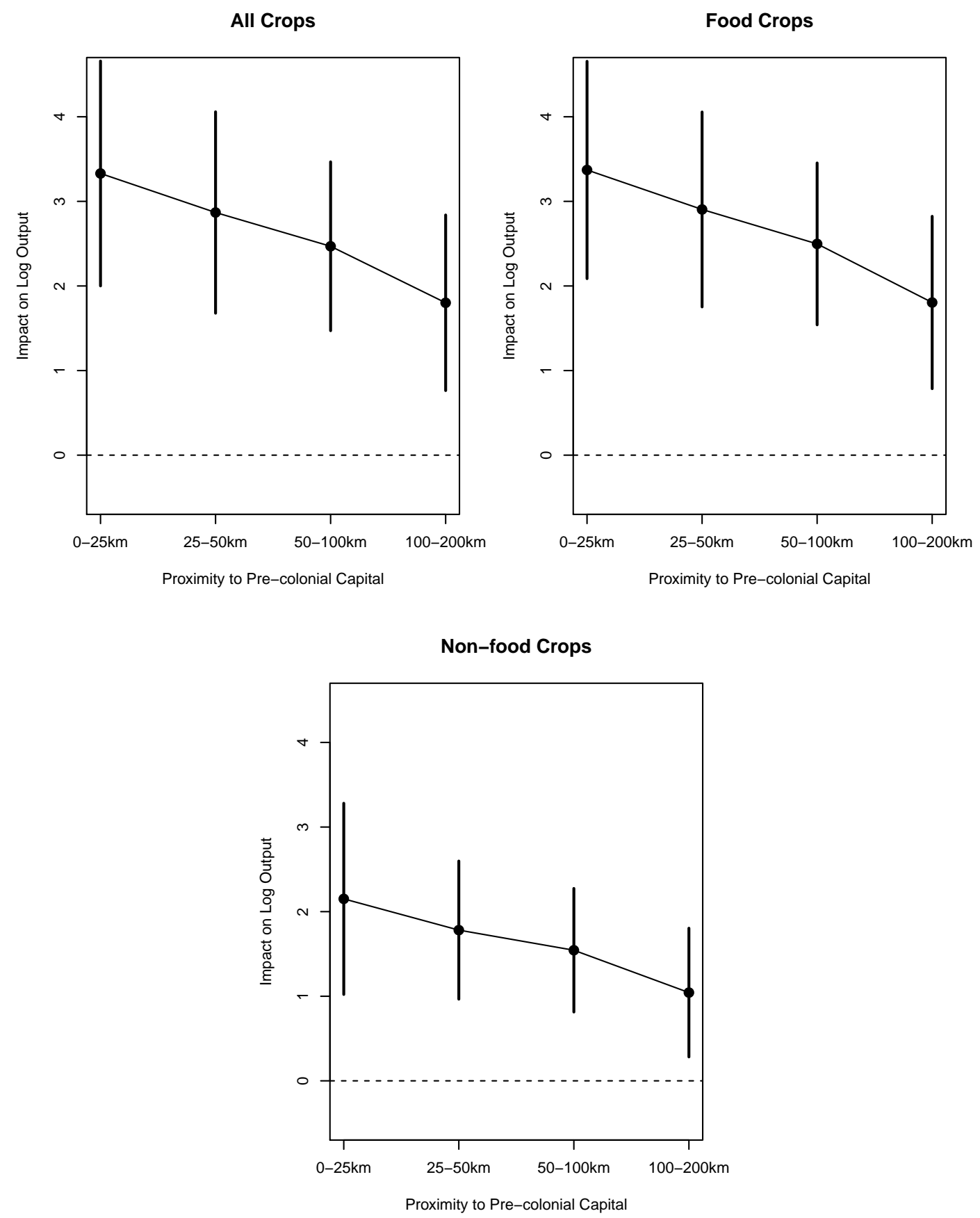

Notes: Plot depicts marginal impact of different levels of proximity to pre-colonial capital on the log of agricultural output, in specification including all three of agro-ecological zone, river basin, and country fixed effects plus controls for terrain slope index, average annual precipitation, and the length of the annual growing period. Standard errors adjusted for three-way clustering within agro-ecological zones, river basins, and countries. Vertical bars represent 95 percent confidence intervals. 
Figure 5: Illustration of Spatial Randomization Test

A. True Location of Capitals

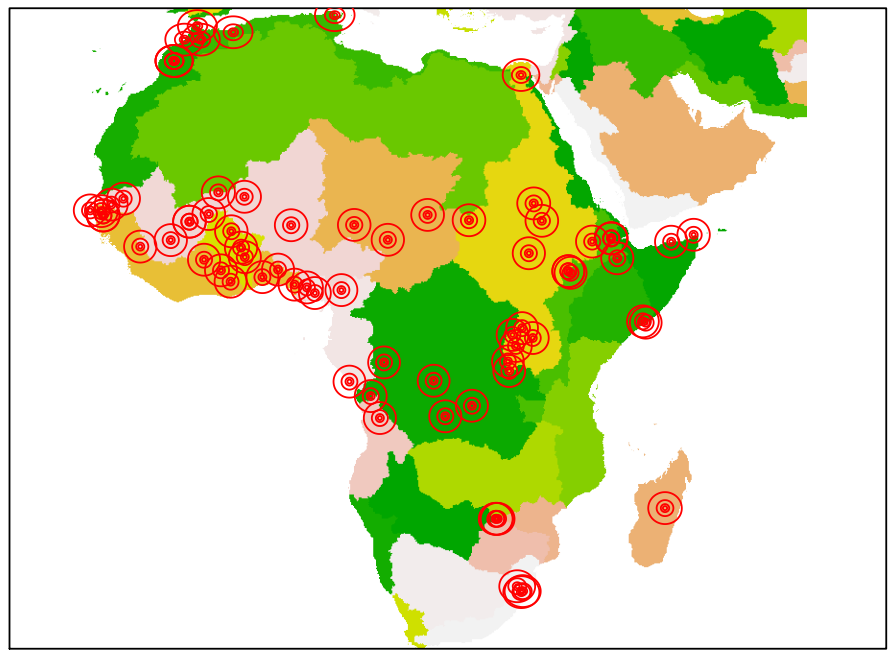

\section{B. Example of Placebo Capitals}

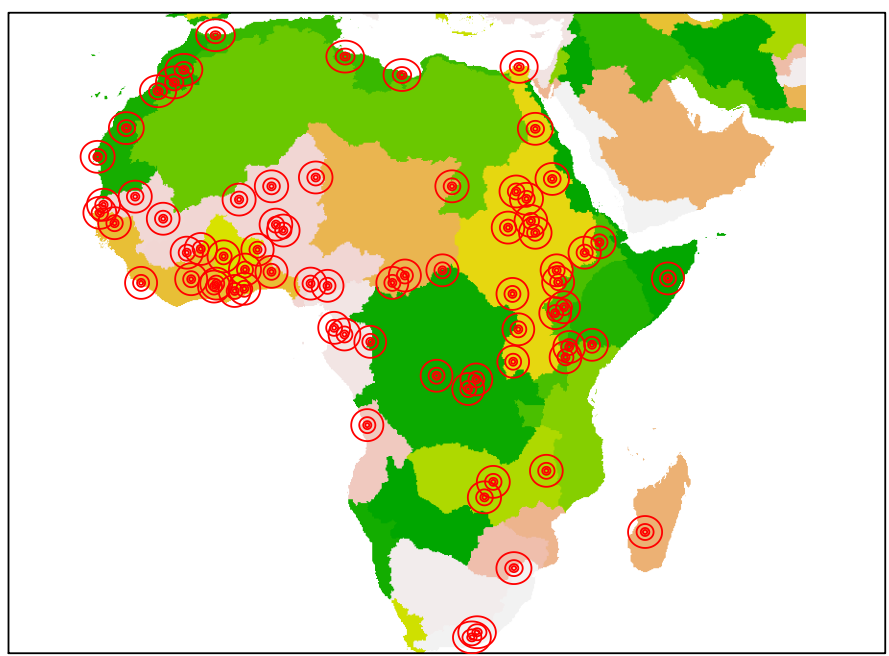

Notes: Panel A depicts river basins along with the true coordinates of pre-colonial capitals. Panel B depicts river basins along with one sample of placebo pre-colonial capitals generated through stratified (within river-basin) random selection of coordinates designed to mimic the spatial distribution of true pre-colonial capitals across river basins. 
Table 2: Spatial Randomization Tests with Placebo Capitals

\begin{tabular}{|c|c|c|c|c|c|c|}
\hline & \multicolumn{3}{|c|}{ All-Africa } & \multicolumn{3}{|c|}{ River basin Stratification } \\
\hline & $\begin{array}{c}\text { All Crops } \\
\text { (1) }\end{array}$ & $\begin{array}{c}\text { Food Crops } \\
\text { (2) }\end{array}$ & $\begin{array}{c}\text { Non-food } \\
\text { (3) }\end{array}$ & $\begin{array}{c}\text { All Crops } \\
\text { (4) }\end{array}$ & $\begin{array}{c}\text { Food Crops } \\
\text { (5) }\end{array}$ & $\begin{array}{c}\text { Non-food } \\
\text { (6) }\end{array}$ \\
\hline Within-25km radius & $\begin{array}{c}0.461 \\
{[\mathrm{p}<0.003]}\end{array}$ & $\begin{array}{c}0.467 \\
{[\mathrm{p}<0.005]}\end{array}$ & $\begin{array}{c}0.369 \\
{[\mathrm{p}<0.000]}\end{array}$ & $\begin{array}{c}0.461 \\
{[\mathrm{p}<0.007]}\end{array}$ & $\begin{array}{c}0.467 \\
{[\mathrm{p}<0.004]}\end{array}$ & $\begin{array}{c}0.369 \\
{[\mathrm{p}<0.015]}\end{array}$ \\
\hline Within-50km radius & $\begin{array}{c}0.399 \\
{[\mathrm{p}<0.005]}\end{array}$ & $\begin{array}{c}0.407 \\
{[\mathrm{p}<0.003]}\end{array}$ & $\begin{array}{c}0.238 \\
{[\mathrm{p}<0.044]}\end{array}$ & $\begin{array}{c}0.399 \\
{[\mathrm{p}<0.011]}\end{array}$ & $\begin{array}{c}0.407 \\
{[\mathrm{p}<0.011]}\end{array}$ & $\begin{array}{c}0.238 \\
{[\mathrm{p}<0.078]}\end{array}$ \\
\hline Within- $100 \mathrm{~km}$ radius & $\begin{array}{c}0.668 \\
{[\mathrm{p}<0.000]}\end{array}$ & $\begin{array}{c}0.693 \\
([\mathrm{p}<0.000]\end{array}$ & $\begin{array}{c}0.500 \\
{[\mathrm{p}<0.001]}\end{array}$ & $\begin{array}{c}0.668 \\
{[\mathrm{p}<0.004]}\end{array}$ & $\begin{array}{c}0.693 \\
([\mathrm{p}<0.000]\end{array}$ & $\begin{array}{c}0.500 \\
{[\mathrm{p}<0.004]}\end{array}$ \\
\hline Within- $200 \mathrm{~km}$ radius & $\begin{array}{c}1.801 \\
{[\mathrm{p}<0.000]}\end{array}$ & $\begin{array}{c}1.804 \\
\mathrm{p}<[0.000]\end{array}$ & $\begin{array}{c}1.043 \\
{[\mathrm{p}<0.000]}\end{array}$ & $\begin{array}{c}1.801 \\
{[\mathrm{p}<0.000]}\end{array}$ & $\begin{array}{c}1.804 \\
\mathrm{p}<[0.000]\end{array}$ & $\begin{array}{c}1.043 \\
{[\mathrm{p}<0.000]}\end{array}$ \\
\hline Observations & 341,830 & 341,830 & 341,830 & 341,830 & 341,830 & 341,830 \\
\hline
\end{tabular}

Notes: Table reports coefficients with spatial randomization p-values in brackets. These tests generate placebo pre-colonial capitals (equal to the number of true capitals in the dataset) with randomly selected spatial coordinates, across Africa in columns (1)-(3) and stratified random generation of coordinates within river basins (mirroring the distribution of true pre-colonial capitals across river basins) in columns (4)-(6). A regression of agricultural output on proximity to these placebo capitals is performed, controlling for agroecological zone, river basin, and country fixed effects. The spatial randomization procedure is repeated 1000 times to generate a distribution of placebo coefficients, from which non-parametric p-values can be computed (the percentage of placebo estimates larger than the estimates based on the true location of pre-colonial capitals). ${ }^{*} \mathrm{p}<0.1$; ${ }^{* *} \mathrm{p}<0.05 ;{ }^{* * *} \mathrm{p}<0.01$ 
Table 3: Impact on Extensive and Intensive Margin

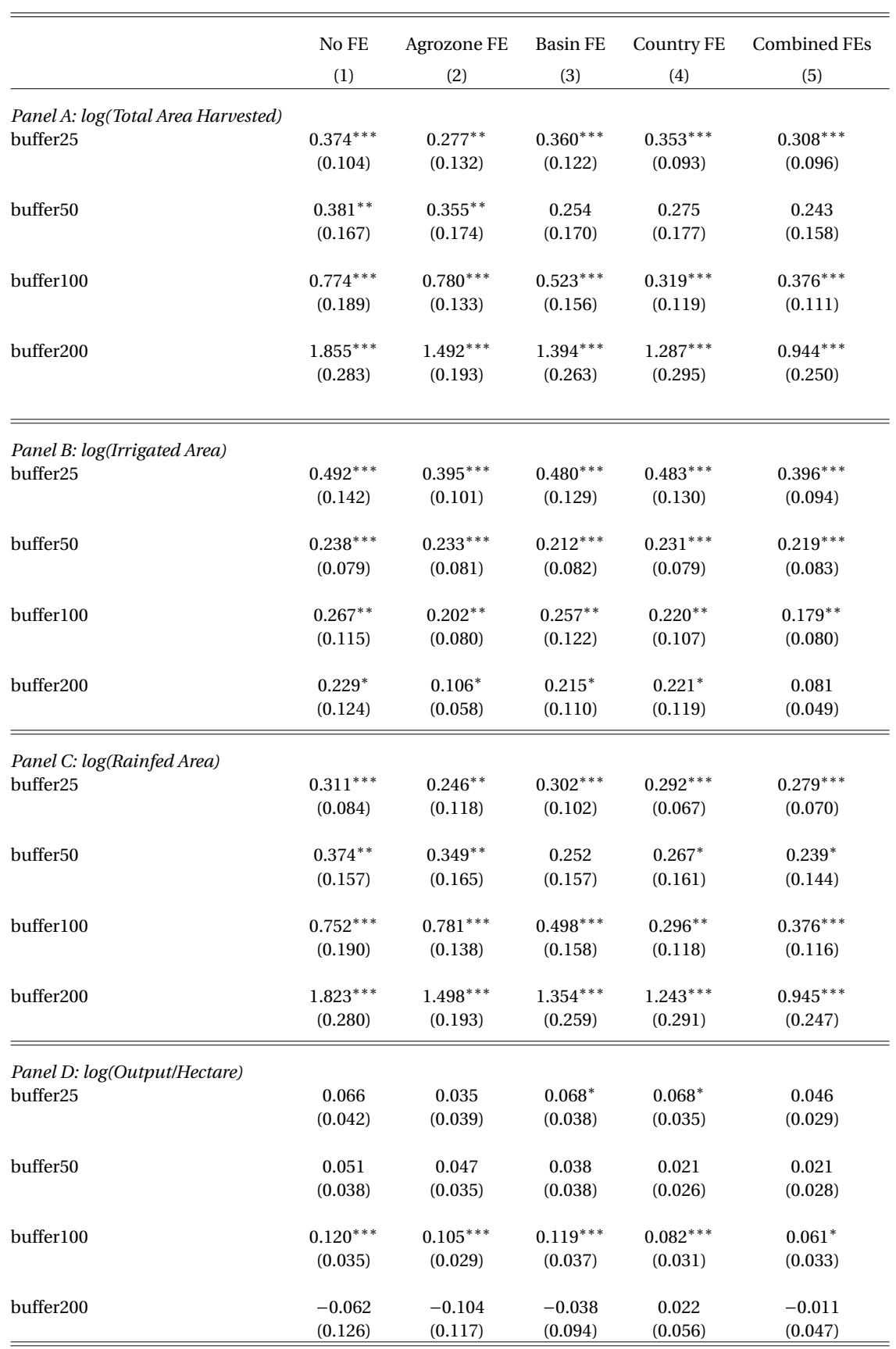

Notes: Unit of analysis is pixels ( $5 \times 5$ arc-minute resolution or approximately $\left.56 \mathrm{~km}^{2}\right)$ on African continent, masking inland water bodies. Explanatory variables are dummy variables for whether a pixel is located within a $25 \mathrm{~km}, 50 \mathrm{~km}, 100 \mathrm{~km}$ or $200 \mathrm{~km}$ ) radius around the location of any pre-colonial capital city in the database. Specifications include, respectively, either no fixed effects, agro-ecological zone fixed effects, river basin fixed effects, country fixed effects, or all three. All specifications control for a terrain slope index, average annual precipitation, and the length of the annual growing period. Standard errors adjusted for three-way clustering within agro-ecological zones, river basins, and countries. ${ }^{*} \mathrm{p}<0.1 ;{ }^{* *} \mathrm{p}<0.05$; $^{* * *} \mathrm{p}<0.01$ 
Figure 6: Marginal Effect of Proximity on Intensive and Extensive Margin
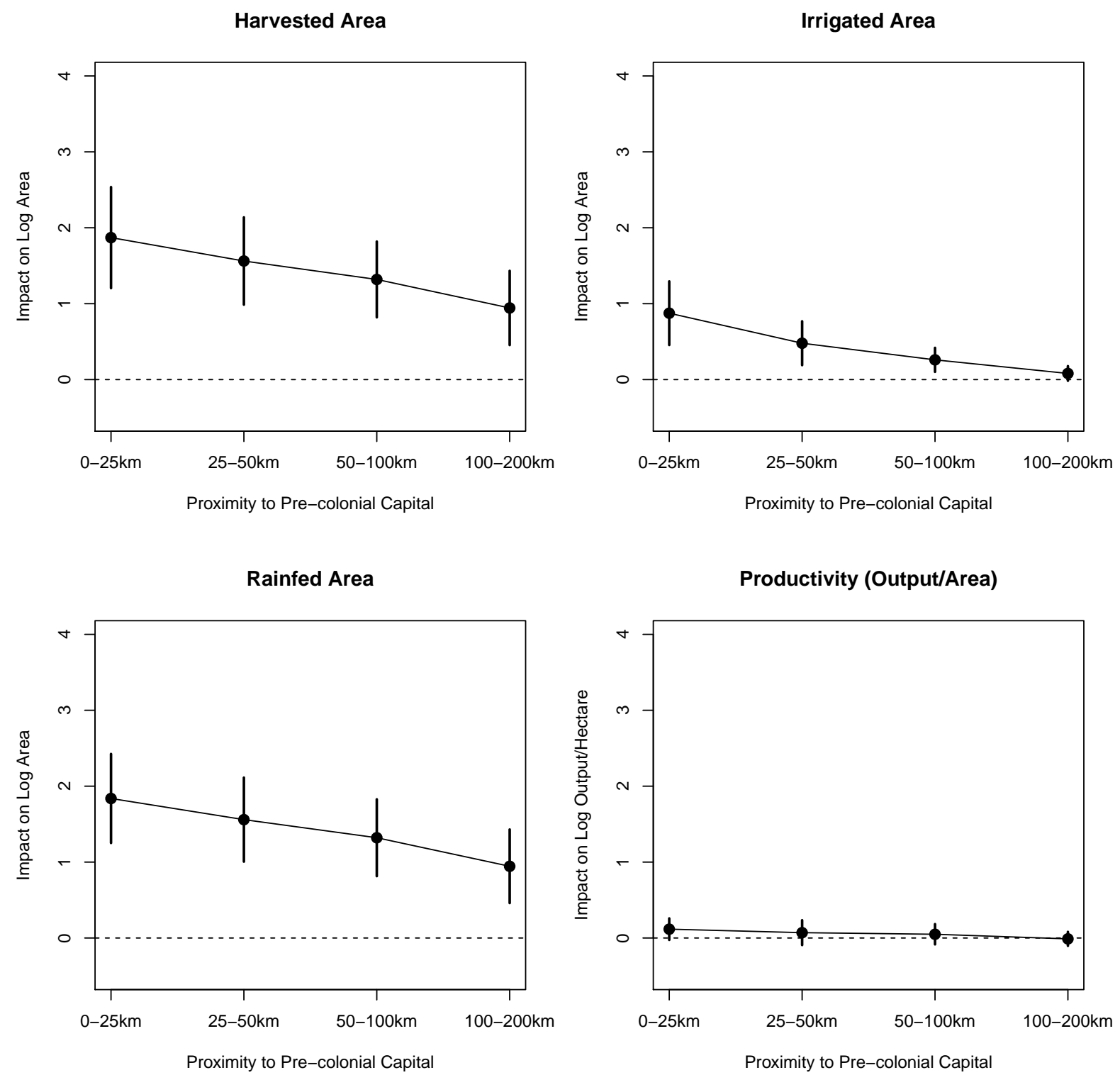

Notes: Plot depicts marginal impact of different levels of proximity to a pre-colonial capital on the extensive and intesive margins of contemporary agricultural productivity, in specification including all three of agroecological zone, river basin, and country fixed effects plus controls for terrain slope index, average annual precipitation, and the length of the annual growing period. Standard errors adjusted for three-way clustering within agro-ecological zones, river basins, and countries. Vertical bars represent 95 percent confidence intervals. 


\section{Table 4: Mechanisms of Persistence: Centralization at Time of Colonization}

\begin{tabular}{|c|c|c|c|c|c|}
\hline & $\begin{array}{l}\text { No FE } \\
\text { (1) }\end{array}$ & $\begin{array}{c}\text { Agrozone FE } \\
(2) \\
\end{array}$ & $\begin{array}{c}\text { Basin FE } \\
(3) \\
\end{array}$ & $\begin{array}{c}\text { Country FE } \\
\text { (4) }\end{array}$ & $\begin{array}{c}\text { Combined FEs } \\
\text { (5) }\end{array}$ \\
\hline $\begin{array}{l}\text { Panel A: State } \\
\text { buffer25 }\end{array}$ & $\begin{array}{c}0.037^{* *} \\
(0.018)\end{array}$ & $\begin{array}{c}0.031^{* *} \\
(0.016)\end{array}$ & $\begin{array}{l}0.038^{*} \\
(0.021)\end{array}$ & $\begin{array}{l}0.037^{*} \\
(0.021)\end{array}$ & $\begin{array}{c}0.035 \\
(0.022)\end{array}$ \\
\hline buffer50 & $\begin{array}{c}0.066^{* * *} \\
(0.024)\end{array}$ & $\begin{array}{c}0.066^{* *} \\
(0.026)\end{array}$ & $\begin{array}{l}0.060^{* *} \\
(0.026)\end{array}$ & $\begin{array}{c}0.059^{* * *} \\
(0.022)\end{array}$ & $\begin{array}{c}0.055^{* *} \\
(0.027)\end{array}$ \\
\hline buffer100 & $\begin{array}{c}0.136^{* * *} \\
(0.029)\end{array}$ & $\begin{array}{c}0.131^{* * *} \\
(0.026)\end{array}$ & $\begin{array}{c}0.126^{* * *} \\
(0.025)\end{array}$ & $\begin{array}{c}0.125^{* * *} \\
(0.030)\end{array}$ & $\begin{array}{c}0.118^{* * *} \\
(0.024)\end{array}$ \\
\hline buffer200 & $\begin{array}{c}0.130^{* * * *} \\
(0.028)\end{array}$ & $\begin{array}{c}0.121^{* * *} \\
(0.026)\end{array}$ & $\begin{array}{c}0.148^{* * *} \\
(0.029)\end{array}$ & $\begin{array}{c}0.136^{* * *} \\
(0.031)\end{array}$ & $\begin{array}{c}0.127^{* * * *} \\
(0.024)\end{array}$ \\
\hline \multicolumn{6}{|c|}{ Panel B: Chiefdom } \\
\hline buffer25 & $\begin{array}{l}-0.015 \\
(0.015)\end{array}$ & $\begin{array}{l}-0.013 \\
(0.015)\end{array}$ & $\begin{array}{l}-0.006 \\
(0.015)\end{array}$ & $\begin{array}{l}-0.012 \\
(0.014)\end{array}$ & $\begin{array}{l}-0.002 \\
(0.014)\end{array}$ \\
\hline buffer50 & $\begin{array}{c}-0.048^{* * *} \\
(0.009)\end{array}$ & $\begin{array}{c}-0.041^{* * *} \\
(0.009)\end{array}$ & $\begin{array}{c}-0.040^{* * *} \\
(0.006)\end{array}$ & $\begin{array}{c}-0.043^{* * *} \\
(0.009)\end{array}$ & $\begin{array}{c}-0.032^{* * *} \\
(0.006)\end{array}$ \\
\hline buffer100 & $\begin{array}{l}-0.029 \\
(0.044)\end{array}$ & $\begin{array}{l}-0.020 \\
(0.045)\end{array}$ & $\begin{array}{l}-0.036 \\
(0.044)\end{array}$ & $\begin{array}{l}-0.038 \\
(0.046)\end{array}$ & $\begin{array}{l}-0.034 \\
(0.038)\end{array}$ \\
\hline buffer200 & $\begin{array}{c}0.013 \\
(0.044)\end{array}$ & $\begin{array}{c}0.028 \\
(0.035)\end{array}$ & $\begin{array}{l}-0.036 \\
(0.033)\end{array}$ & $\begin{array}{l}-0.019 \\
(0.040)\end{array}$ & $\begin{array}{c}-0.037^{*} \\
(0.022)\end{array}$ \\
\hline \multicolumn{6}{|c|}{ Panel C: Acephalous } \\
\hline buffer25 & $\begin{array}{c}0.015 \\
(0.015)\end{array}$ & $\begin{array}{c}0.013 \\
(0.015)\end{array}$ & $\begin{array}{c}0.006 \\
(0.015)\end{array}$ & $\begin{array}{c}0.012 \\
(0.014)\end{array}$ & $\begin{array}{c}0.002 \\
(0.014)\end{array}$ \\
\hline buffer50 & $\begin{array}{c}0.048^{* * *} \\
(0.009)\end{array}$ & $\begin{array}{c}0.041^{* * *} \\
(0.009)\end{array}$ & $\begin{array}{c}0.040^{* * *} \\
(0.006)\end{array}$ & $\begin{array}{c}0.043^{* * *} \\
(0.009)\end{array}$ & $\begin{array}{c}0.032^{* * *} \\
(0.006)\end{array}$ \\
\hline buffer100 & $\begin{array}{c}0.029 \\
(0.044)\end{array}$ & $\begin{array}{c}0.020 \\
(0.045)\end{array}$ & $\begin{array}{c}0.036 \\
(0.044)\end{array}$ & $\begin{array}{c}0.038 \\
(0.046)\end{array}$ & $\begin{array}{c}0.034 \\
(0.038)\end{array}$ \\
\hline buffer200 & $\begin{array}{l}-0.013 \\
(0.044) \\
\end{array}$ & $\begin{array}{l}-0.028 \\
(0.035) \\
\end{array}$ & $\begin{array}{c}0.036 \\
(0.033) \\
\end{array}$ & $\begin{array}{c}0.019 \\
(0.040) \\
\end{array}$ & $\begin{array}{l}0.037^{*} \\
(0.022) \\
\end{array}$ \\
\hline Observations & 340,694 & 340,694 & 340,694 & 340,694 & 340,694 \\
\hline
\end{tabular}

Notes: Unit of analysis is pixels $\left(5 \times 5\right.$ arc-minute resolution or approximately $\left.56 \mathrm{~km}^{2}\right)$ on African continent, masking inland water bodies. Explanatory variables are dummy variables for whether a pixel is located within a $25 \mathrm{~km}, 50 \mathrm{~km}, 100 \mathrm{~km}$ or $200 \mathrm{~km}$ ) radius around the location of any pre-colonial capital city in the database. Specifications include, respectively, either no fixed effects, agro-ecological zone fixed effects, river basin fixed effects, country fixed effects, or all three. All specifications control for a terrain slope index, average annual precipitation, and the length of the annual growing period. Standard errors adjusted for four-way clustering within ethnic homelands, agro-ecological zones, river basins, and countries. ${ }^{*} \mathrm{p}<0.1$; ${ }^{* *} \mathrm{p}<0.05$; ${ }^{* * *} \mathrm{p}<0.01$ 


\section{Figure 7: Marginal Effect of Proximity on Centralization at Time of Colonization}
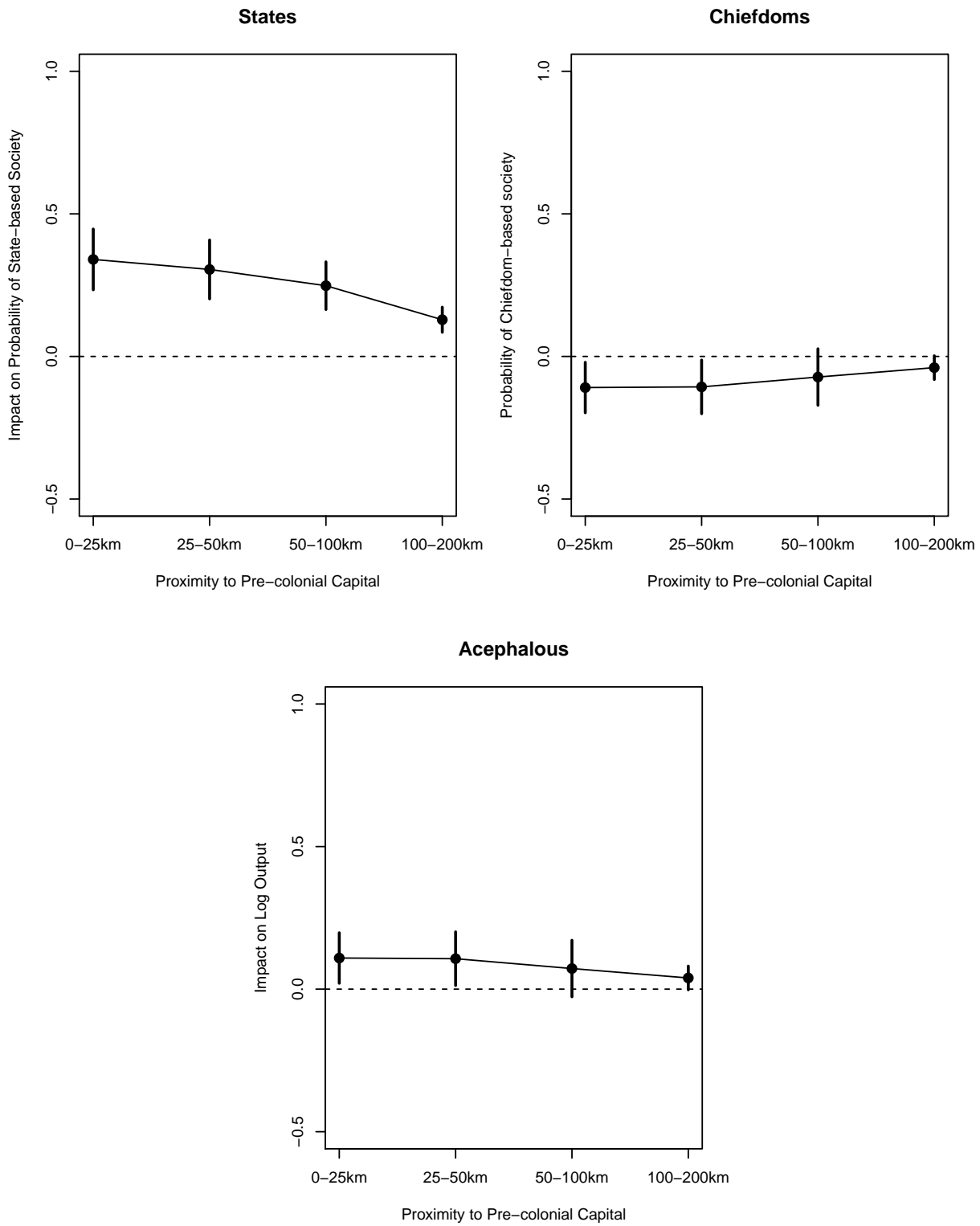

Notes: Plot depicts marginal impact of different levels of proximity to a pre-colonial capital on nature of political organization across ethnic homelands at time of colonization based on Murdock (1967), in specification including all three of agro-ecological zone, river basin, and country fixed effects plus controls for terrain slope index, average annual precipitation, and the length of the annual growing period. Standard errors adjusted for four-way clustering within ethnic homelands, agro-ecological zones, river basins, and countries. Vertical bars represent 95 percent confidence intervals. 
Table 5: Impact on Territorial Reach of Contemporary States

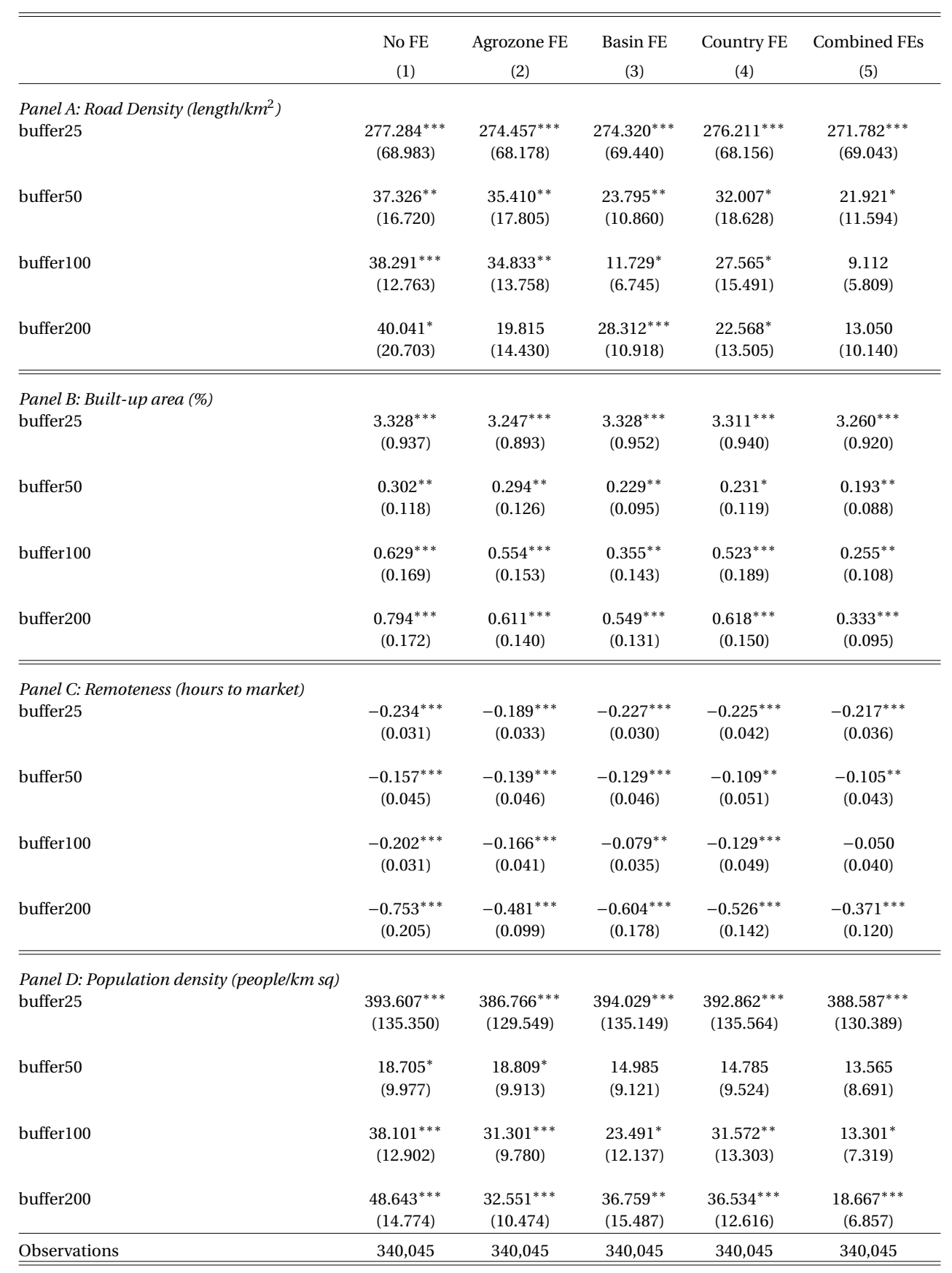

Notes: Unit of analysis is pixels $\left(5 \times 5\right.$ arc-minute resolution or approximately $\left.56 \mathrm{~km}^{2}\right)$ on African continent, masking inland water bodies. Explanatory variables are dummy variables for whether a pixel is located within a $25 \mathrm{~km}, 50 \mathrm{~km}, 100 \mathrm{~km}$ or $200 \mathrm{~km}$ ) radius around the location of any pre-colonial capital city in the database. Specifications include, respectively, either no fixed effects, agro-ecological zone fixed effects, river basin fixed effects, country fixed effects, or all three. All specifications control for a terrain slope index, average annual precipitation, and the length of the annual growing period. Standard errors adjusted for three-way clustering within agro-ecological zones, river basins, and countries. ${ }^{*} \mathrm{p}<0.1 ;{ }^{* *} \mathrm{p}<0.05 ;{ }^{* * *} \mathrm{p}<0.01$ 
Figure 8: Marginal Effect of Proximity on Reach of State
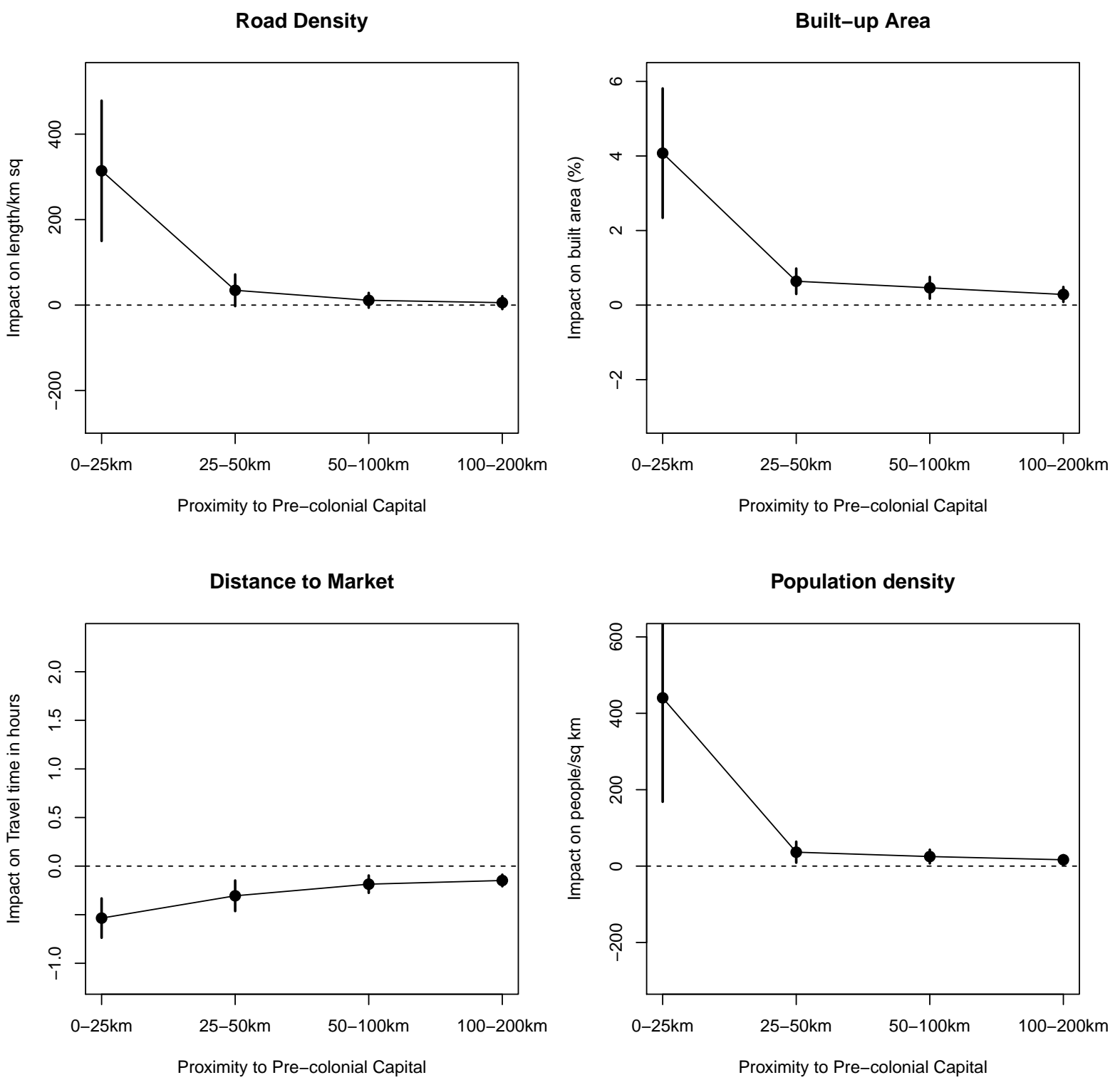

Notes: Plot depicts marginal impact of different levels of proximity to a pre-colonial capital on the extensive and intesive margins of contemporary agricultural productivity, in specification including all three of agroecological zone, river basin, and country fixed effects plus controls for terrain slope index, average annual precipitation, and the length of the annual growing period. Standard errors adjusted for three-way clustering within agro-ecological zones, river basins, and countries. Vertical bars represent 95 percent confidence intervals. 


\section{APPENDIX}

Precolonial States and Development: Evidence from Agriculture in Africa
Aditya Dasgupta
Ada Johnson-Kanu 


\section{Identifying Pre-Colonial African States}

We assemble a list of pre-colonial African states that were in existence between 1500 and 1850 . We select states within this period as these states existed right before the partitioning of Africa in the 1880's and thus should have most recently transmitted institutions through to the colonial and post-colonial periods. In compiling this list, we first identify prominent states studied by archeologists, anthropologists, and historians. Historical and archeological research provides a rich resource for understanding the society Africans in precolonial times lived in. These scholarship provide information on the government structure, economy, and societal hierarchies that determine the ruling class. From this, we code variables on economic activities and political administration present in these precolonial states.

Our dataset comprises 82 precolonial states spread across the entire continent. For each precolonial state, we code the capital cities from which state leaders - the kings, their advisers, and the ruling class - administer the state. In most states, there exists at least one capital administrative city from which the states reach is projected. Where a state has more than 1 capital city recorded in its existence, we use the most recent capital city in our analysis. For two states, we do not find evidence of a capital city from which the state was administered. In our database, multiple states may share a single capital city where one state succeeds another and retains the administrative city of the previous state.

Table A1 shows the list of precolonial states included in our database. The table is a snapshot of the database and shows the states and their respective capital cities. The full database includes indicators for the time period the state existed, if they were centralized, whether they had 
taxation, the type of currency they used in trade, and other pertinent indicators for pre-colonial state administrative capacities. These indicators are by no means exhaustive of the characteristics of these states gleamed from historical and archeological literature.

TABLE A1

\begin{tabular}{|c|c|c|c|c|}
\hline State & In Current state & Period & Capital Cities & Capital Coordinates \\
\hline $\begin{array}{l}\text { Kingdom of Alodia/ } \\
\text { Kingdom of Alwa }\end{array}$ & Sudan/South Sudan & $\begin{array}{l}7-1504 \\
1227 / 1229-\end{array}$ & Soba & $15^{\circ} 31^{\prime} 26^{\prime \prime} \mathrm{N} 32^{\circ} 40^{\prime} 51^{\prime \prime}$ \\
\hline $\begin{array}{l}\text { Hafsid dynasty } \\
\text { Kingdom of } \\
\text { Tlemcen }\end{array}$ & Tunisia & $\begin{array}{l}1574 \\
1235- \\
1556 / 1554\end{array}$ & $\begin{array}{l}\text { Tunis } \\
\text { Tlemcen }\end{array}$ & $\begin{array}{l}36^{\circ} 48^{\prime} 23^{\prime \prime} \mathrm{N} 10^{\circ} 10^{\prime} 54^{\prime \prime} \mathrm{E} \\
34^{\circ} 52^{\prime} 58^{\prime \prime} \mathrm{N} 01^{\circ} 19^{\prime} 00^{\prime \prime} \\
\mathrm{W}\end{array}$ \\
\hline $\begin{array}{l}\text { Mamluk sultanate } \\
\text { wattasid dynasty } \\
\text { (in the Marinid }\end{array}$ & Egypt (Cairo), Syria & $1250-1517$ & Cairo & $30^{\circ} 2^{\prime} \mathrm{N} 31^{\circ} 14^{\prime} \mathrm{E}$ \\
\hline dynasty) & $\begin{array}{l}\text { Morocco } \\
\text { Sudan, Eritrea, }\end{array}$ & $1420-1554$ & Fez & $34^{\circ} 2^{\prime} \mathrm{N} 5^{\circ} \mathrm{O}^{\prime} \mathrm{W}$ \\
\hline $\begin{array}{l}\text { sultanate of sennar } \\
\text { Saadi principality } \\
\text { of Sus and }\end{array}$ & Ethiopia & $\begin{array}{l}1504-1821 \\
(1509-1554\end{array}$ & $\begin{array}{l}\text { Sennar } \\
\text { Taroudant // }\end{array}$ & $13^{\circ} 33^{\prime} \mathrm{N} 33^{\circ} 35^{\prime} \mathrm{E}$ \\
\hline Tagmadert & Morocco & $\begin{array}{l}\text { CE) } \\
(1554-1659\end{array}$ & $\begin{array}{l}\text { Marrakesh } \\
\text { Taroudant // }\end{array}$ & $31^{\circ} 37^{\prime} 48^{\prime \prime} \mathrm{N} 8^{\circ} 0^{\prime} 32^{\prime \prime} \mathrm{W}$ \\
\hline $\begin{array}{l}\text { Saadi dynasty } \\
\text { Naqsid principality }\end{array}$ & Morocco & $\begin{array}{l}\text { CE) } \\
(1597-1673\end{array}$ & Marrakesh & $31^{\circ} 37^{\prime} 48^{\prime \prime} \mathrm{N} 8^{\circ} 0^{\prime} 32^{\prime \prime} \mathrm{W}$ \\
\hline of Tetouan & Morocco & $\begin{array}{l}\text { CE) } \\
(1603-1874 \&\end{array}$ & Tetouan & $35^{\circ} 34^{\prime} \mathrm{N} 5^{\circ} 22^{\prime} \mathrm{W}$ \\
\hline $\begin{array}{l}\text { Sultanate of } \\
\text { Darfur } \\
\text { Republic of Bou }\end{array}$ & Sudan & $\begin{array}{l}1898-1916 \\
\text { CE) } \\
(1627-1668\end{array}$ & Al fashir & $13^{\circ} 37^{\prime} 50^{\prime \prime} \mathrm{N} 25^{\circ} 21^{\prime} 0^{\prime \prime} \mathrm{E}$ \\
\hline Regreg & Morocco & CE) & $\begin{array}{l}\text { Rabat } \\
\text { Rotated } \\
\text { between }\end{array}$ & $34^{\circ} 02^{\prime} \mathrm{N} 6^{\circ} 50^{\prime} \mathrm{W}$ \\
\hline Alaouite dynasty & Morocco & $\begin{array}{l}\text { (1666-current } \\
\text { CE) }\end{array}$ & $\begin{array}{l}\text { Rabat, Fez, } \\
\text { Marrakech } \\
\text { Gondar } \\
\text { (1635-1855); } \\
\text { Magdala } \\
\text { (1855-1868); }\end{array}$ & $31^{\circ} 37^{\prime} 48^{\prime \prime} \mathrm{N} 8^{\circ} 0^{\prime} 32^{\prime \prime} \mathrm{W}$ \\
\hline $\begin{array}{l}\text { Solomonic } \\
\text { dynasty }\end{array}$ & Ethiopia & $\begin{array}{l}(1270-1974 \\
\text { CE) }\end{array}$ & $\begin{array}{l}\text { Mekelle } \\
(1871-1885)\end{array}$ & $11^{\circ} 12^{\prime} \mathrm{N} 39^{\circ} 17^{\prime} \mathrm{E}$ \\
\hline
\end{tabular}




\begin{tabular}{|c|c|c|c|c|}
\hline Warsangali & & (1298-1886 & & \\
\hline Sultanate & Somalia & CE) & Las Khorey & $11^{\circ} 11^{\prime} \mathrm{N} 48^{\circ} 13^{\prime} \mathrm{E}$ \\
\hline Kingdom of & & (1300-present & & \\
\hline Bunyoro & Uganda & CE) & Hoima & $01^{\circ} 25^{\prime} 55^{\prime \prime} \mathrm{N} 31^{\circ} 21^{\prime} 09^{\prime \prime} \mathrm{E}$ \\
\hline Kingdom of & & (1300-present & & \\
\hline Buganda & Uganda & CE) & Kampala & $00^{\circ} 18^{\prime} 49^{\prime \prime} \mathrm{N} 32^{\circ} 34^{\prime} 52^{\prime \prime} \mathrm{E}$ \\
\hline Kingdom of & & (1300-1959 & & \\
\hline Rwanda & Rwanda & $\begin{array}{l}\text { CE) } \\
\text { (14th century- } \\
\text { 17th century }\end{array}$ & Nyanza & $2^{\circ} 21^{\prime} 06^{\prime \prime} \mathrm{S} 29^{\circ} 45^{\prime} 03^{\prime \prime} \mathrm{E}$ \\
\hline Ajuran Sultanate & Somalia & CE) & $\begin{array}{l}\text { Mogadishu } \\
\text { Zeila /Dakkar }\end{array}$ & $02^{\circ} 02^{\prime} \mathrm{N} 45^{\circ} 20^{\prime} \mathrm{E}$ \\
\hline & Djibouti, Ethiopia, & (1415-1555 & / Harar & \\
\hline Adal Sultanate & Somaliland & CE) & $\begin{array}{l}\text { /Aussa } \\
\text { Zeila / Dakkar } \\
\text { / Harar / }\end{array}$ & $11^{\circ} 34^{\prime} \mathrm{N} 41^{\circ} 26^{\prime} \mathrm{E}$ \\
\hline Sultanate of Harar & Ethiopia & $(1526-1577)$ & Aussa & $11^{\circ} 34^{\prime} \mathrm{N} 41^{\circ} 26^{\prime} \mathrm{E}$ \\
\hline Emirate of Harar & Ethiopia, Somalia & $\begin{array}{l}\text { (1647-1887) } \\
\text { (Late 15th }\end{array}$ & Ge (Harar) & $9^{\circ} 19^{\prime} \mathrm{N} 42^{\circ} 7^{\prime} \mathrm{E}$ \\
\hline $\begin{array}{l}\text { Ankole Kingdom } \\
\text { Kingdom of }\end{array}$ & Uganda & $\begin{array}{l}\text { century-1967) } \\
(1530-1966\end{array}$ & Mbarara & $00^{\circ} 36^{\prime} 48^{\prime \prime} \mathrm{S} 30^{\circ} 39^{\prime} 30^{\prime \prime} \mathrm{E}$ \\
\hline Burundi & Burundi & $\begin{array}{l}\text { CE) } \\
(1545-1861\end{array}$ & $\begin{array}{l}\text { Gitega } \\
\text { Fashoda }\end{array}$ & $3^{\circ} 26^{\prime} \mathrm{S} 29^{\circ} 54^{\prime} \mathrm{E}$ \\
\hline Shilluk Kingdom & South Sudan & $\begin{array}{l}\text { CE) } \\
\text { (late 17th } \\
\text { century-late }\end{array}$ & (Kodok) & $9^{\circ} 53^{\prime} \mathrm{N} 32^{\circ} 07^{\prime} \mathrm{E}$ \\
\hline Sultanate of the & & 19th century & & \\
\hline Geledi & Somalia & $\begin{array}{l}\text { CE) } \\
\text { (fl. 1734- }\end{array}$ & Afgooye & $2^{\circ} 11^{\prime} 16^{\prime \prime} \mathrm{N} 45^{\circ} 01^{\prime} 00^{\prime \prime} \mathrm{E}$ \\
\hline Sultanate of Aussa & Ethiopia & $\begin{array}{l}\text { present CE) } \\
\text { (mid-18th } \\
\text { century-early }\end{array}$ & Aussa (Asiata) & $11^{\circ} 34^{\prime} \mathrm{N} 41^{\circ} 26^{\prime} \mathrm{E}$ \\
\hline Majeerteen & & 20th century & & \\
\hline Sultanate & Somalia & CE) & Alula & $11^{\circ} 58^{\prime} 0^{\prime \prime} \mathrm{N} 50^{\circ} 45^{\prime} 0^{\prime \prime} \mathrm{E}$ \\
\hline Kingdom of Nri & Nigeria & $\begin{array}{l}\text { (948-1911 CE) } \\
\text { (11th-19th }\end{array}$ & Igbo-Ukwu & $\begin{array}{l}6^{\circ} 1^{\prime} \mathrm{N} 7^{\circ} 1^{\prime} \mathrm{E} \\
45^{\circ} 42^{\prime} 0.612^{\prime \prime} \mathrm{N}\end{array}$ \\
\hline $\begin{array}{l}\text { Bonoman } \\
\text { Kingdom of }\end{array}$ & Ghana & century $\mathrm{CE}$ ) & Bono Manso & $8^{\circ} 46^{\prime} 30.288^{\prime \prime} \mathrm{E}$ \\
\hline Bamum & $\begin{array}{l}\text { Cameroon } \\
\text { Ghana, Burkina, }\end{array}$ & $\begin{array}{l}\text { (1394-1884) } \\
\text { (11th century- }\end{array}$ & fumban & $5^{\circ} 43^{\prime} \mathrm{N} 10^{\circ} 55^{\prime} \mathrm{E}$ \\
\hline Mossi Kingdoms & Faso & $\begin{array}{l}1896 \text { CE }) \\
(1180-1897\end{array}$ & Ouagadougou & $12^{\circ} 22^{\prime} \mathrm{N} 1^{\circ} 32^{\prime} \mathrm{W}$ \\
\hline Benin Empire & $\begin{array}{l}\text { Nigeria } \\
\text { Senegal, } \\
\text { Mauritania, Mali, } \\
\text { Burkina Faso, } \\
\text { Niger, Gambia, Gui } \\
\text { nea-Bissau, Guinea, }\end{array}$ & $\begin{array}{l}\text { (1235-1600 } \\
\text { CE) decline } \\
\text { from } 1400\end{array}$ & Benin & $6^{\circ} 20^{\prime} 00^{\prime \prime} \mathrm{N} 5^{\circ} 37^{\prime} 20^{\prime \prime} \mathrm{E}$ \\
\hline
\end{tabular}




\begin{tabular}{|c|c|c|c|c|}
\hline & $\begin{array}{l}\text { Cote d'Iviore, } \\
\text { Ghana }\end{array}$ & & & \\
\hline Jolof Empire & Senegal, Gambia & $\begin{array}{l}(1350-1889 \\
C E) \\
(1400-1895\end{array}$ & Linguere & $15^{\circ} 23^{\prime} 40^{\prime \prime} \mathrm{N} 15^{\circ} 7^{\prime} 0^{\prime \prime} \mathrm{W}$ \\
\hline $\begin{array}{l}\text { Oyo Empire } \\
\text { Kingdom of }\end{array}$ & Nigeria, Benin & CE) & Oyo-ile (oyo) & $8^{\circ} 2^{\prime} 0^{\prime \prime} \mathrm{N} 3^{\circ} 45^{\prime} 0^{\prime \prime} \mathrm{E}$ \\
\hline Dagbon & Ghana & $\begin{array}{r}\text { (1409-Ce?) } \\
\text { (14th-19th }\end{array}$ & Yendi & $\begin{array}{l}09^{\circ} 26.5^{\prime} \mathrm{N} 00^{\circ} 0.5^{\prime} \mathrm{W} \\
14^{\circ} 09^{\prime} 41^{\prime \prime} \mathrm{N} 16^{\circ} 01^{\prime} 51^{\prime \prime}\end{array}$ \\
\hline Kingdom of Sine & Senegal & $\begin{array}{l}\text { century CE) } \\
(1464-1591\end{array}$ & Kahone & W \\
\hline $\begin{array}{l}\text { Songhai Empire } \\
\text { Pashalik of }\end{array}$ & Niger, Mali & CE) & Gao & $16^{\circ} 16^{\prime} \mathrm{N} 0^{\circ} 03^{\prime} \mathrm{W}$ \\
\hline Timbuktu & Mali & 1591-1833 & Timbuktu & $16^{\circ} 46^{\prime} 33^{\prime \prime} \mathrm{N} 3^{\circ} 00^{\prime} 34^{\prime \prime} \mathrm{W}$ \\
\hline $\begin{array}{l}\text { Dendi Kingdom } \\
\text { Empire of Great }\end{array}$ & Niger & $\begin{array}{l}(1591-1901) \\
(1490-1776\end{array}$ & Lulami & \\
\hline $\begin{array}{l}\text { Fulo } \\
\text { Kingdom of }\end{array}$ & Senegal, Gambia & $\begin{array}{l}\text { CE) } \\
(1494-1969\end{array}$ & Anyam-Godo & $14^{\circ} 09^{\prime} 41^{\prime \prime} \mathrm{N} 16^{\circ} 01^{\prime} 51^{\prime \prime}$ \\
\hline Saloum & Senegal & $\begin{array}{l}\text { CE) } \\
\text { (16th century }\end{array}$ & Kahone & W \\
\hline Mamprussi & Ghana, Togo & $\begin{array}{l}\text { CE-?) } \\
(1537-1867\end{array}$ & Gambaga & $10^{\circ} 31^{\prime} 50^{\prime \prime} \mathrm{N} 0^{\circ} 26^{\prime} 32^{\prime \prime} \mathrm{W}$ \\
\hline Kaabu Empire & Senegal, Gambia & $\begin{array}{l}\text { CE) } \\
(1549-1879\end{array}$ & Kansala & $14^{\circ} 43^{\prime} 26^{\prime \prime} \mathrm{N}$ \\
\hline Kingdom of Cayor & Senegal & $\begin{array}{l}\text { CE) } \\
(1555-1874\end{array}$ & Mboul & $\begin{array}{l}17^{\circ} 29^{\prime} 31^{\prime \prime} \mathrm{W} \\
14^{\circ} 39^{\prime} 07.7^{\prime \prime} \mathrm{N} 16^{\circ} 14^{\prime} 02 .\end{array}$ \\
\hline $\begin{array}{l}\text { Kingdom of Baol } \\
\text { Kingdom of }\end{array}$ & Senegal & $\begin{array}{l}\text { CE) } \\
(1600-1900\end{array}$ & Diourbel & $5^{\prime \prime} \mathrm{W}$ \\
\hline Dahomey & Benin & $\begin{array}{l}\text { CE) } \\
(1690-1902\end{array}$ & Abomey & $7^{\circ} 11^{\prime} 8^{\prime \prime} \mathrm{N} 1^{\circ} 59^{\prime} 17^{\prime \prime} \mathrm{E}$ \\
\hline Aro Confederacy & Nigeria & CE) & Arochukwu & $5^{\circ} 23^{\prime} \mathrm{N} 7^{\circ} 55^{\prime} \mathrm{E}$ \\
\hline $\begin{array}{l}\text { Abron Kingdom of } \\
\text { Gyaman }\end{array}$ & $\begin{array}{l}\text { Ghana, Cote } \\
\text { d'Ivoire }\end{array}$ & $\begin{array}{l}(1450-1895) \\
(1701-1894\end{array}$ & Sampa & $7^{\circ} 57^{\prime} \mathrm{N} 2^{\circ} 42^{\prime} \mathrm{W}$ \\
\hline Asante Union & $\begin{array}{l}\text { Ghana } \\
\text { Cote d'Ivoire, }\end{array}$ & $\begin{array}{l}\text { CE) } \\
(1710-1894\end{array}$ & Kumasi & $6^{\circ} 40^{\prime} \mathrm{N} 1^{\circ} 37^{\prime} \mathrm{W}$ \\
\hline Kong Empire & $\begin{array}{l}\text { Burkina Faso } \\
\text { Nigeria Niger }\end{array}$ & $\begin{array}{l}\text { CE) } \\
1400 ?-1804\end{array}$ & $\begin{array}{l}\text { Kong } \\
\text { indenendents }\end{array}$ & $9^{\circ} 9^{\prime} \mathrm{N} 4^{\circ} 37^{\prime} \mathrm{W}$ \\
\hline & & (1712-1861 & & \\
\hline $\begin{array}{l}\text { Bamana Empire } \\
\text { Kanem-Bornu }\end{array}$ & Mali & $\begin{array}{l}\text { CE) } \\
\text { (9th century- }\end{array}$ & Segou & $13^{\circ} 27^{\prime} \mathrm{N} 6^{\circ} 16^{\prime} \mathrm{W}$ \\
\hline Empire & $\begin{array}{l}\text { Chad, Niger, Nigeria } \\
\text { Angola, DRC, Congo }\end{array}$ & $\begin{array}{l}1900 \mathrm{CE}) \\
(1400-1888\end{array}$ & $\begin{array}{l}\text { Ngazargamu } \\
\text { M'banza- }\end{array}$ & $13^{\circ} 05^{\prime} \mathrm{N} 12^{\circ} 22^{\prime} \mathrm{E}$ \\
\hline $\begin{array}{l}\text { Kingdom of Kongo } \\
\text { Sultanate of }\end{array}$ & Republic & $\begin{array}{l}\text { CE) } \\
(1522-1897\end{array}$ & Kongo & $6^{\circ} 16^{\prime} 04^{\prime \prime} \mathrm{S} 14^{\circ} 14^{\prime} 53^{\prime \prime} \mathrm{E}$ \\
\hline Bagirmi & $\begin{array}{l}\text { Chad } \\
\text { Democratic }\end{array}$ & $\begin{array}{l}\text { CE) } \\
(1585-1885\end{array}$ & Massenya & $\begin{array}{l}11^{\circ} 24^{\prime} \mathrm{N} 16^{\circ} 10^{\prime} \mathrm{E} \\
7^{\circ} 21^{\prime} 34.4^{\prime \prime S}\end{array}$ \\
\hline Luba Empire & Republic of Congo & CE) & Mwibele & $25^{\circ} 40^{\prime} 42.4^{\prime \prime} \mathrm{E}$ \\
\hline
\end{tabular}




\begin{tabular}{|c|c|c|c|c|}
\hline \multirow{2}{*}{\multicolumn{2}{|c|}{ Kingdom of }} & \multirow[b]{2}{*}{ (16th century- } & \multicolumn{2}{|l|}{ Kabasa (now } \\
\hline & & & Caculo & \\
\hline Ndongo & Angola & ? CE) & (abaça) & $8^{\circ} 45^{\prime} 0^{\prime \prime S} 15^{\circ} 16^{\prime} 0^{\prime \prime E}$ \\
\hline Kingdom of & & (1631-1744 & Matamba / & $8^{\circ} 59^{\prime} 22.8228^{\prime \prime S}$ \\
\hline Matamba & Angola & CE) & Kindoga & $33^{\circ} 58^{\prime} 6.276^{\prime \prime} \mathrm{E}$ \\
\hline & Chad, Central & (1635-1912 & & \\
\hline Wadai Empire & African Republic & CE) & Ouara & 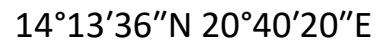 \\
\hline & Congo, Angola, & (1665-1887 & & \\
\hline Kingdom of Lunda & Zambia & CE) & Musumba & $8^{\circ} 33^{\prime} 33^{\prime \prime} \mathrm{S} 22^{\circ} 40^{\prime} 57^{\prime \prime} \mathrm{E}$ \\
\hline & Democratic & (1600-present & & \\
\hline Kuba Kingdom & Republic of Congo & CE) & Nsheng & $4^{\circ} 32^{\prime} 00^{\prime \prime} \mathrm{S} 21^{\circ} 21^{\prime} 00^{\prime \prime} \mathrm{E}$ \\
\hline Kingdom of & Mozambique, & $(1430-1760$ & & \\
\hline Mutapa & Zambia, Zimbabwe & CE) & Zvongombe & \\
\hline & & $(1450-1683$ & & \\
\hline Kingdom of Butua & $\begin{array}{l}\text { Zimbabwe } \\
\text { Malawi, }\end{array}$ & CE) & Khami & $20^{\circ} 09^{\prime} 30^{\prime \prime} \mathrm{S} 28^{\circ} 22^{\prime} 36^{\prime \prime} \mathrm{E}$ \\
\hline $\begin{array}{l}\text { Kingdom of } \\
\text { Maravi }\end{array}$ & $\begin{array}{l}\text { Mozambique, } \\
\text { Zambia }\end{array}$ & & Manthimba & \\
\hline & & (1660-1866 & & \\
\hline Rozwi Empire & Zimbabwe & CE) & $\begin{array}{l}\text { Danamombe } \\
\text { KwaBulawayo } \\
\text { / }\end{array}$ & $20^{\circ} 08^{\prime} 35^{\prime \prime} \mathrm{S} 28^{\circ} 25^{\prime} 23^{\prime \prime} \mathrm{E}$ \\
\hline Ndwandwe & & (1780-1819 & umGungundlo & \\
\hline Kingdom & South Africa, & $\begin{array}{l}\text { CE) } \\
\text { (18th century- }\end{array}$ & vu / Ulundi & $28^{\circ} 19^{\prime} \mathrm{S} 31^{\circ} 25^{\prime} \mathrm{E}$ \\
\hline Merina Kingdom & $\begin{array}{l}\text { Madagascar } \\
\text { South Africa, }\end{array}$ & $1896 \mathrm{CE})$ & Antananarivo & $18^{\circ} 56^{\prime} \mathrm{S} 47^{\circ} 31^{\prime} \mathrm{E}$ \\
\hline Mthethwa & eSwatini, & (18th century- & & \\
\hline Paramountcy & Mozambique & $\begin{array}{l}1820 \mathrm{CE}) \\
\text { (early 19th }\end{array}$ & Vryheid & $27^{\circ} 46^{\prime} 01^{\prime \prime} \mathrm{S} 30^{\circ} 48^{\prime} 00^{\prime \prime} \mathrm{E}$ \\
\hline $\begin{array}{l}\text { Kingdom of } \\
\text { Gomma }\end{array}$ & Ethiopia & $\begin{array}{l}\text { century- } \\
1886)\end{array}$ & Agaro & $7^{\circ} 51^{\prime} \mathrm{N} 36^{\circ} 35^{\prime} \mathrm{E}$ \\
\hline $\begin{array}{l}\text { Kingdom of Jimma } \\
\text { Kingdom of }\end{array}$ & Ethiopia & $(1830-1932)$ & Jiren (Jimma) & $7^{\circ} 40^{\prime} \mathrm{N} 36^{\circ} 50^{\prime} \mathrm{E}$ \\
\hline Gumma & Ethiopia & $(1840-1902)$ & Agaro & $7^{\circ} 51^{\prime} \mathrm{N} 36^{\circ} 35^{\prime} \mathrm{E}$ \\
\hline Sokoto Caliphate & Nigeria, Niger & $(1804-1903)$ & Sokoto & $13^{\circ} 03^{\prime} 44^{\prime \prime} \mathrm{N} 5^{\circ} 14^{\prime} 02^{\prime \prime} \mathrm{E}$ \\
\hline Toucouleur Empire & Mali, Senegal & $(1848-1893)$ & $\begin{array}{l}\text { Segou } \\
\text { Ulundi / }\end{array}$ & $13^{\circ} 27^{\prime} \mathrm{N} 6^{\circ} 16^{\prime} \mathrm{W}$ \\
\hline & & & uMgungundlo & $28^{\circ} 26^{\prime} 9.23^{\prime \prime S} 31^{\circ} 16^{\prime} 3.3$ \\
\hline Zulu Kingdom & South Africa & $\begin{array}{l}\text { (1816-1897) } \\
\text { (1830-precent }\end{array}$ & vu / Bulawayo & $5 " \mathrm{E}$ \\
\hline Tooro Kingdom & Uganda & CE) & Fort portal & $\begin{array}{l}00^{\circ} 39^{\prime} 16^{\prime \prime} \mathrm{N} 30^{\circ} 16^{\prime} 28^{\prime \prime} \mathrm{E} \\
4^{\circ} 38^{\prime} 01.0^{\prime \prime} \mathrm{S}\end{array}$ \\
\hline Loango Kingdom & Congo, DRC & $1550-1883$ & Loango & $11^{\circ} 49^{\prime} 40.8^{\prime \prime} \mathrm{E}$ \\
\hline & & & & $2^{\circ} 27^{\prime} 40.0^{\prime \prime S}$ \\
\hline $\begin{array}{l}\text { Tio Kingdom } \\
\text { Imamate of Futa }\end{array}$ & Congo & & Monsol & $15^{\circ} 44^{\prime} 25.7^{\prime \prime} \mathrm{E}$ \\
\hline Toro & Senegal & $(1776-1861)$ & Orefonde & $16^{\circ} 3^{\prime} 0^{\prime \prime} \mathrm{N} 13^{\circ} 44^{\prime} \mathrm{O}=\mathrm{W}$ \\
\hline
\end{tabular}




\begin{tabular}{|c|c|c|c|c|}
\hline & & & & $20^{\circ} 08^{\prime} 60.00^{\prime \prime} \mathrm{S}$ \\
\hline Ndabele State & Zimbabwe & & Old Bulawayo & $28^{\circ} 34^{\prime} 59.99^{\prime \prime E}$ \\
\hline $\begin{array}{l}\text { Macina Empire } \\
\text { Imamate of Futa }\end{array}$ & Mali & $1818-1962$ & Hamdullahi & $14^{\circ} 19^{\prime} 52^{\prime \prime} \mathrm{N} 4^{\circ} 05^{\prime} 45^{\prime \prime} \mathrm{W}$ \\
\hline jalon & Guinea & $1725-1912$ & Timbo & $10^{\circ} 38^{\prime} \mathrm{N} 11^{\circ} 50^{\prime} \mathrm{W}$ \\
\hline
\end{tabular}

